
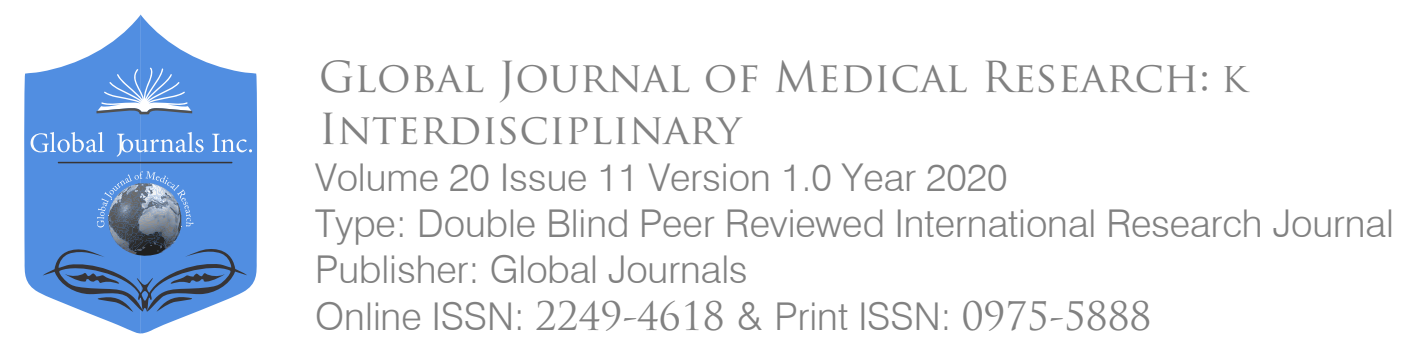

\title{
Vaccine, Emergence, Termination, Sunspot Number as ON-OFF Switch for COVID-19 Pandemic with 25 Worst-Hit Countries
}

By Tai-Jin Kim

University of Suwon

Abstract- COVID-19 vaccine sample at Arctic Ocean and Antarctic Peninsula, plasmas from recovered people and CMV infected cetaceans, and modified MMR vaccines with the cetacean host. The present study proposes that the11-year cyclic sunspot number is analogous to a SWITCH, turning on and off an epidemic, inducing a public-health crisis. The ON period by the minimum (maximum) sunspot number initiated mutant viruses (AIV, SARS, MERS-CoV, and COVID-19) to transmit from the Poles to Continents by migratory birds and humpback whales. The first COVID-19 arrival dates in China, USA, Japan, Mexico, and Hawaii, determined by the distance between feeding grounds and breeding areas of humpback whale habitats. The OFF period occurs during the high sunspot number (>25-50) and may terminate COVID-19 in September (optimistic prediction) or in November, 2020 (pessimistic prediction) with three cases. Leather tanning industry $\left(R^{2}=0.8514\right)$, global coastline $\left(R^{2}=0.7864\right)$, USA coastline $\left(R^{2}=\right.$ $0.3099)$, USA refinery $\left(R^{2}=0.4874\right), \mathrm{CO}_{2}$ emissions $\left(R^{2}=0.7627\right)$, population $\left(R^{2}=0.3748\right)$, and minimum sunspot number $\left(\mathrm{R}^{2}=0.8907\right)$ showed high linearity with COVID-19 pandemic, as major causes in the 25worst-hit countries. COVID-19 can globally decrease by reducing toxic chemicals during the leather industry.

Keywords: cetacean host vaccine, emergence, termination, sunspot number, ON-OFF Switch, COVID-19 Pandemic, 25 Worst-Hit Countries.

GJMR-K Classification: NLMC Code: QW 800

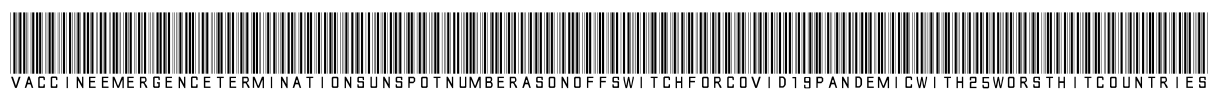

Strictly as per the compliance and regulations of:

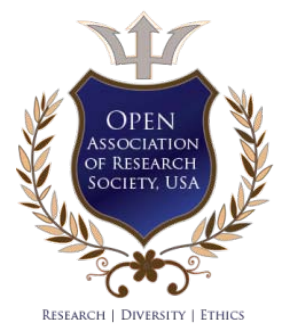

(C) 2020. Tai-Jin Kim. This is a research/review paper, distributed under the terms of the Creative Commons AttributionNoncommercial 3.0 Unported License http://creativecommons.org/licenses/by-nc/3.0/), permitting all non-commercial use, distribution, and reproduction in any medium, provided the original work is properly cited. 


\title{
Vaccine, Emergence, Termination, Sunspot Number as ON-OFF Switch for COVID-19 Pandemic with 25 Worst-Hit Countries
}

\author{
Tai-Jin Kim
}

\begin{abstract}
COVID-19 vaccine sample at Arctic Ocean and Antarctic Peninsula, plasmas from recovered people and CMV infected cetaceans, and modified MMR vaccines with the cetacean host. The present study proposes that the11-year cyclic sunspot number is analogous to a SWITCH, turning ON and OFF an epidemic, inducing a public-health crisis. The ON period by the minimum (maximum) sunspot number initiated mutant viruses (AIV, SARS, MERS-CoV, and COVID-19) to transmit from the Poles to Continents by migratory birds and humpback whales. The first COVID-19 arrival dates in China, USA, Japan, Mexico, and Hawaii, determined by the distance between feeding grounds and breeding areas of humpback whale habitats. The OFF period occurs during the high sunspot number (>25-50) and may terminate COVID-19 in September (optimistic prediction) or in November, 2020 (pessimistic prediction) with three cases. Leather tanning industry $\left(R^{2}=0.8514\right)$, global coastline $\left(R^{2}=0.7864\right)$, USA coastline $\left(R^{2}=0.3099\right)$, USA refinery $\left(R^{2}=0.4874\right), \mathrm{CO}_{2}$ emissions $\left(R^{2}=0.7627\right)$, population $\left(R^{2}=0.3748\right)$, and minimum sunspot number $\left(\mathbf{R}^{2}=0.8907\right)$ showed high linearity with COVID-19 pandemic, as major causes in the 25worst-hit countries. COVID-19 can globally decrease by reducing toxic chemicals during the leather industry.
\end{abstract}

Keywords: cetacean host vaccine, emergence, termination, sunspot number, ON-OFF Switch, COVID-19 Pandemic, 25 Worst-Hit Countries.

\section{INTRODUCTION}

T he coronavirus (COVID-19) has infected 188 countries and regions with more than $13,765,713$ total and 589,192 deaths as of July 17, 2020 (JOHNS HOPKINS, 2020), to becoming the worst public-health crisis in a century (CALLAWAY et al., 2020). The coronavirus (COVID-19) is spreading around the world, but there are still no vaccines to protect the body against the COVID-19. Ten candidate vaccines are in clinical evaluation while 123 candidate vaccines are in preclinical evaluation (WHO, 2020). The COVID-19 might be an evolutionary virus mixed between species of humans and cetaceans (porpoises, dolphins and whales) (KIM, 2020). Therefore, the transmitters of the COVID-19 are multi-species- humans and cetaceans, which could be why 188 countries and regions suddenly suffered from the COVID-19 within a few months.

Author: e-mail: tjkim@suwon.ac.kr
The present study proposes vaccine, protection, emergence, propagation, and termination associated with the coronavirus (COVID-19) pandemic. Furthermore, the fundamental causes of COVID-19 are to investigate parameters such as leather tanning and processing, oil refineries, gas- and coal-powered plants, safe latitude with total ozone, vehicles, population, carbon dioxide emissions, humpback whale districts, volcanic regions, migratory birds, dolphins with coastline, and preventive measures. The case study for the 25 worst-hit countries includes 1. USA, 2. Brazil, 3. India, 4. Russia, 5.Peru, 6. Chile, 7. The United Kingdom,8. Mexico, 9. Spain, 10. Iran, 12. Italy, 15. Turkey, 16. France, 17. Germany, 20. Canada, 23. China, 25. Sweden, 26. Indonesia, 29. Ecuador, 30. Belgium, 35. Philippines, 37. Netherlands, 44. Israel, 56. Japan, and64. South Korea, with a number of the global, confirmed rank as of July 10, 2020.

\section{EXPERIMENT}

a) The Vaccine with Cetacean Host

i. Step 1. Search of Host. Viruses are roughly spherical $(80 \sim 120 \mathrm{~nm})$ with glycoprotein spikes on the surface and genome consisting of eight RNA fragments that encode 10 proteins. Since there is currently 18 hemagglutinin $(\mathrm{HA})$, and 11 neuraminidase (NA) subtypes and matrix (M2) proteins embed in the envelope lipid bilayer derived from the host cell, 198 combinations with 4 strains of $A, B, C$ and $D(C D C, 2017)$. The requirements of low titers of vaccines and safe production without causing SARS-like diseases (SINOBIOLOGICAL, 2020) are met if searching the right host for theCOVID-19. Several animals such as bats, rodents, cattle, swine, and dromedary camels considered as hosts and sources of six endemic human coronaviruses (CORMAN et al., 2018). However, no one has yet proposed the cetaceans (porpoises, dolphins, and whales) as reservoirs of the COVID-19, while recent works (KIM, 2019 and 2020) illustrated the cetaceans as the host of the COVID-19 pandemic. Most of the coronavirus vaccine development concentrated on the coronavirus SARS-CoV-2(CALLAWAY, 2020) and SARS-CoV vaccine (SINOBIOLOGICAL, 2020). The 
induction by viruses for SARS and MERS-CoV was the coronavirus. At the same time each transmission reservoir was the bat for SARS in China in 2002-2003 and the bat/dromedary camel in Saudi Arabia in 2012, respectively (KIM, 2019). The humpback whales were the transmitter of the avian influenza virus (AIV), while their stranding along the Atlantic Coast from 1992 to 2016 related $\left(R^{2}=\right.$ 0.6128 ) with $\mathrm{CO}_{2}$ emissions from the states on the Atlantic Coast in the USA (KIM, 2018). Furthermore, Kim (2019) proposed that humpback whales in Site \# 3 among 14 habitats were the source of the COVID-19 in Wuhan in China. Kim (2020) revealed warning phenomena, originally referred to by Ward (2019) and Sorace (2019), stating that there were over 100 and 136 dead dolphins found stranded on the beach of Cape Verde of West Africa (Site \# 2) (KIM, 2020) on September 28 and 30, respectively, 2019, which happened ahead of the COVID-19 emergence on November 17 in Wuhan in China. The sudden spread of the COVID-19 in 2020 could have caused by the 14 habitats of humpback whales, linked to millions of dolphins(KIM, 2020). The COVID-19 deaths cases of the top 15 worst-hit countries were proportional $\left(R^{2}=0.7864\right)$ to the lengths of swimming coastlines (Fig. 5) along which cetaceans swim. It is clear that cetaceans, including porpoises (KIM, 2019), dolphins, and whales (KIM, 2020), are the host and the source of the COVID-19 pandemic. The COVID-19 vaccine should thus develop not in the limited realm of SARS-CoV-2 coronavirus, but the wide domain of cetacean coronaviruses such as the cetacean morbillivirus (CMV). CMV has a high propensity for interspecies transmission (JO et al., 2018). CMV is RNA viruses, as is the case of the COVID-19, recognized in 1988 with several distinct viral strains (LEGER et al., 2018) such as;1. Porpoise morbillivirus (PMV), 2. Dolphin morbillivirus (DMV), 3. Pilot whale morbillivirus (PWMV), 4. Beaked whale morbillivirus (BWMV), 5. Long-finned pilot Longman's beaked whale, 6. Guinea dolphin, and 7. Indo-Pacific bottlenose dolphin, the latter caused the COVID-19 pandemic in Wuhan in China (KIM, 2019).

ii. Step 2. Screenings.1) Human blood test for the presence of a non-segmented, single-stranded RNA genome (MODROW et al., 2013) of negative polarity for the COVID-19, may allow the initial screening of the confirmed cases by blood kit. 2) The final confirmation can decide by CT (computerized tomography) film for pulmonary calcification. 3) The COVID-19 induces pneumonia, inflaming the alveoli in the lung filled with pus, causing a smell from toxic gases such as $\mathrm{H}_{2} \mathrm{~S}, \mathrm{SO}_{2}, \mathrm{NH}_{3}$, and mercaptans. A portable $\mathrm{H}_{2} \mathrm{~S}$ detector in a ppm unit for the foul smell of pus from human exhaled air, quickly screens the degree of lung inflammation, caused by the COVID19. $\mathrm{H}_{2} \mathrm{~S}$ is also available from volcanic gas (0.04$0.68 \%)(\mathrm{KIM}, 2020)$ and biogas (0.5 - $2 \%)$ (DUMONT, 2015), so that the concentration of pus smell is within a toxic allowance of $10 \mathrm{ppm}$ or 0.001 $\%$. Therefore, a commercial portable $\mathrm{H}_{2} \mathrm{~S}$ detector easily monitors the foul smell of pus from human exhaled air, if infected by the COVID-19. 4) Those whose body temperature show higher than $37.5^{\circ} \mathrm{C}$ $\left(99.5^{\circ} \mathrm{F}\right)$, should be separated from the normal group for accurate measurement. Such simple screenings of physical (body temperature), chemical $\left(\mathrm{H}_{2} \mathrm{~S}\right.$ detector), biological (blood test), and radiological (computerized tomography) kits may quickly separate patients infected from the COVID-19 from the healthy ones.

iii. Step 3.COVID-19 Vaccine.1) Vaccines can develop with virus samples collected at the Chukchi Sea of the Arctic Ocean for the feeding grounds of gray whales and at the Baffin Bay of the Arctic Ocean for the ones of humpback whales, respectively. Virus samples can also collect at the Antarctic Peninsula of the Antarctic with the warmest areas by the potent UV-B radiation. 2) Culturing plasma from people recovered from COVID-19 (PIECHOTTA et al., 2020) and plasma from CMV infected cetaceans.3) 4 kinds of plasma preparations depending on the source (humans and cetaceans) and virus diseases (COVID-19 and CMV) as; fresh human plasma, human plasma infected by COVID19, fresh cetacean plasma, and cetacean one infected by CMV.4) Plasma inoculates and incubates at $37^{\circ} \mathrm{C}$, as for CMV (WENDY et al., 2018). The virus inactivates at a temperature to use as one of 5 types of vaccines (CDC, 2018); 1. live attenuated vaccines, 2 . inactivated ones, 3 . toxic ones, 4. subunit ones, and 5. conjugate ones.5) The vaccine application to humans can follow by the stepwise methods in vitro P3 Lab test at petri dish, for the initial efficacy of curing the human lung cell infected by the COVID-19. In vivo tests for confirmed, recovered, and healthy people, determine the final efficacy and the stability of the developed COVID-19 vaccines to prevent the COVID-19. 6) Finally, the developed vaccines should examine to protect the human body's immune system for the mass reduction of the COVID-19 symptoms (CALLAWAY et al., 2020). Cetacean morbillivirus (CMV) and measles morbillivirus (MV) belong to morbillivirus. Since MV have humans as hosts, the MMR (Measles, Mumps, and Rubella) vaccine can be a good candidate to protect humans from the COVID-19. The genetic modification of MMR vaccines with the cetaceans host, may allow the low titers of the attenuated COVID-19 vaccines to last long and be safe. 
b) Emergence of COVID-19

As for the emergence of COVID-19, the breeding period of the humpback whales14 habitats (KIM, 2020) begins from December to April (NOAA, 2015). The human incubation period is from 2-14 days to possible outliners 0-27 days (WORLDOMETER, 2020). Adding one month for the human incubation period of COVID-19 to December, it expects that the COVID-19 would emerge in January 2020. On January 19, 2020, a 35-year-old man in Seattle of Washington was the first case of COVID-19 in the USA (CGTN AMERICA, 2020), while on January 16, 2020, there was the first case of COVID-19 in Japan (WHO, 2020). The feeding grounds of humpback whales are the same Bering Sea in Alaska, while their breeding grounds distribute in Japan, China, Taiwan, and South Korea (Site \#3), Hawaii (\# 4), and Baja Mexico (\#5) (KIM, 2020). The coastline of Washington is $4,870 \mathrm{~km}$ and the 11thlongest in the USA. Due to the proximity of whale feeding grounds in Alaska and Seattle $(2,641 \mathrm{~km})$, it is not necessary to add another month to January as a migratory period. Such an additional month added to January can be applicable if the route is from Alaska to another breeding area of Baja California of Mexico with a distance of $4,374 \mathrm{~km}$. Thus, the first case of COVID-19 in Mexico was February 28, 2020 cited as arrival date (WHO, 2020), which was close to one month added to the case of Seattle (January 19, 2020). The distance between Hawaii (\# 4) and the Bering Sea in Alaska is $4,486 \mathrm{~km}$, which is a little farther than Baja California of Mexico (\# 5). If we subtract 4,374 km in Baja California in Mexico (February 28, 2020) from 4,486 km in Hawaii, the answer is five additional days to February 28, 2020, considering the average whale swimming speed of 22 $\mathrm{km}$ per hour. The result means an exact match with the first arrival date of March 6, 2020, in Hawaii (WHO, 2020).

It can conclude that the arrival dates of the COVID-19 in Seattle in the USA, Japan, Mexico, and Hawaii, can determine by the swimming distance between the feeding ground and the breeding ones of humpback whale habitats. As for China, there was the first case of COVID-19 in Wuhan on November 17, 2019 (WHO, 2020). Ward (2019) observed over 100 dead dolphins found dead on the beach of Cape Verde of West Africa on September 28, 2019. The distance between Cape Verde and Wuhan in China can determine as follows: Cape Verde to South Africa $(7,098$ $\mathrm{km})$, from South Africa to Shanghai in China $(12,434$ $\mathrm{km})$, from Shanghai to Wuhan in China $(690 \mathrm{~km})$. The total is $20,222 \mathrm{~km}$. The distance of $20,222 \mathrm{~km}$, divided by $22 \mathrm{~km}$ per hour for whale speed, provides the 38.3 days required as traveling time from Cape Verde to Wuhan. If 38.3 days add to the observed date by Ward (2019), September 28, 2019, the resulting time was November 7,2019 . Since the human incubation period of the COVID-19 was 2-14 days (WHO, 2020), the expected date of the COVID-19's emergence in Wuhan in China was between November 9, 2019 and November 21, 2019 while actual emergence date in China was November 17, 2019. It is certain that the date of the COVID-19 emergence in Wuhan in China agrees with distance swam by cetaceans from Cape Verde to Wuhan in China. China has the largest $\mathrm{CO}_{2}$ emissions which might cause the largest ozone hole area and the highest UV-B radiation $(\mathrm{NIH}, 1989)$ for the earliest emergence of the coronavirus (COVID-19) in the world (KIM, 2019).

\section{c) Propagation of COVID-19}

The coronavirus (COVID-19) has infected188 countries and regions with more than $13,765,713$ total cases and 589,192 deaths as of July 17, 2020 (JOHNS HOPKINS, 2020), becoming the worst public-health crisis in a century (CALLAWAY et al., 2020). The population of the 25 worst-hit countries in the present study was proportional $\left(R^{2}=0.3748\right)$ to the COVID-19 deaths cases, as shown in Fig. 1. China (1,390 million) and India (1,340 million) excluded due to being out of range. Fig. 1 showed that the more populated countries showed more COVID-19 deaths. In the rank of deaths as of July 10,2020, the population of each country was as follows; 1. USA 325 million, 2. Brazil 209, 3. India 134, 4. Russia 145, 5. Peru 32, 6. Chile 18, 7. U.K. 66,8. Mexico 130, 9. Spain 47, 10. Iran 81, 11. Italy 61,15 . Turkey 81, 16. France 67, 17. Germany 83, 20. Canada. 37, 23. China 1,390, 25. Sweden 10,26. Indonesia 264, 29. Ecuador 17,30. Belgium 12, 35. Philippines 107, 37. Netherlands 17, 44. Israel 9,56. Japan 127, 64. South Korea 52.

The top $5 \mathrm{CO}_{2}$ emitting countries are; 1 . China, 2. USA, 3. India, 4. Russia, 5. Japan, while $\mathrm{CO}_{2}$ emissions correlated with total cases $\left(R^{2}=0.8064\right)$ and deaths $\left(R^{2}=0.7627\right)$ of the COVID-19 (KIM, 2020).It is necessary to reduce the global population to decrease $\mathrm{CO}_{2}$ emissions as well as the COVID-19, as shown in Fig. 1. 


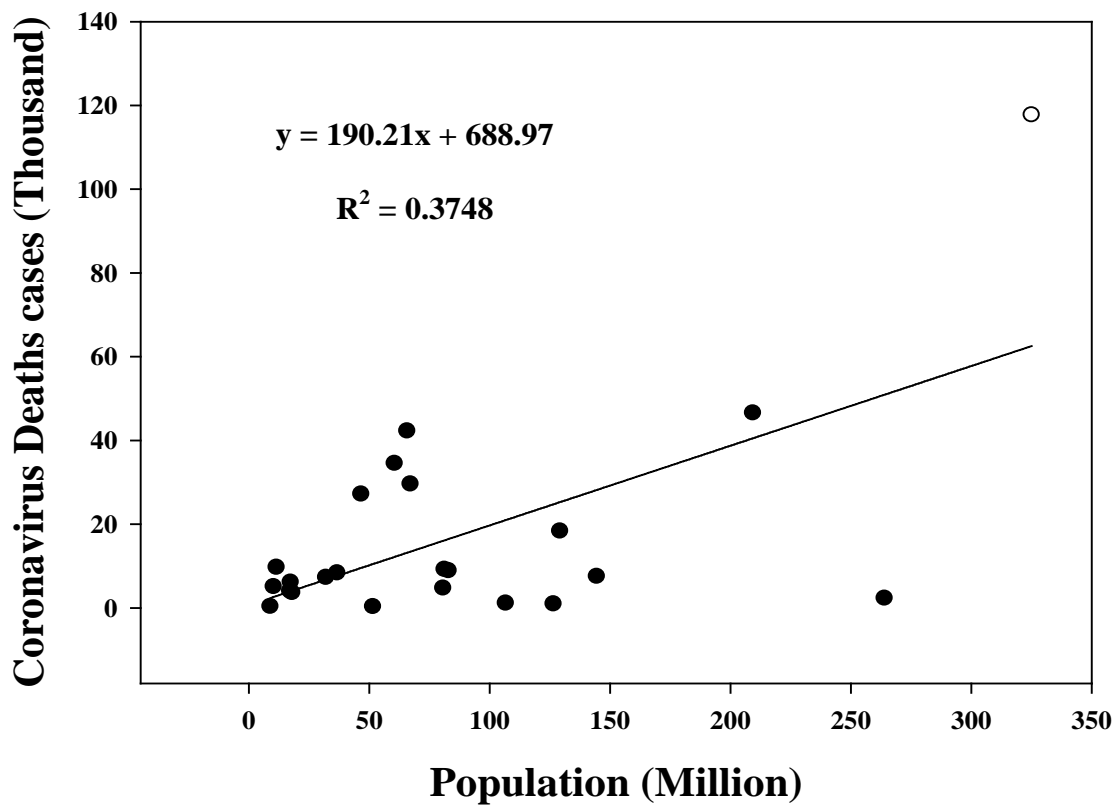

Figure 1: The population (million) of 25 worst-hit countries was proportional $\left(R^{2}=0.3748\right)$ to the COVID-19 deaths cases (thousand).

Table 1 showed that the highest linearity of COVID-19 deaths with the leather tanning industry $\left(R^{2}=\right.$ $0.8514)$ and the coastline (cetaceans) $\left(R^{2}=0.7864\right)$, while COVID-19 deaths linearly correlated with the lumped parameter of $\mathrm{CO}_{2}$ emissions $\left(\mathrm{R}^{2}=0.7627\right)$. It is necessary to reduce the global COVID-19 deaths by the controllable variable of $\mathrm{CO}_{2}$ emissions, which originated from leather tanning, oil refineries, vehicles, coal- and gas-powered plants, population, and metropolitan food waste gas. Since the parameters such as coastlines or cetaceans, ozone hole area, and minimum sunspot number are not controllable variables, the most effective parameter $\left(R^{2}=0.8514\right)$ of the leather tanning industry can globally decrease the COVID-19 deaths by reducing toxic chemicals during the leather tanning process.

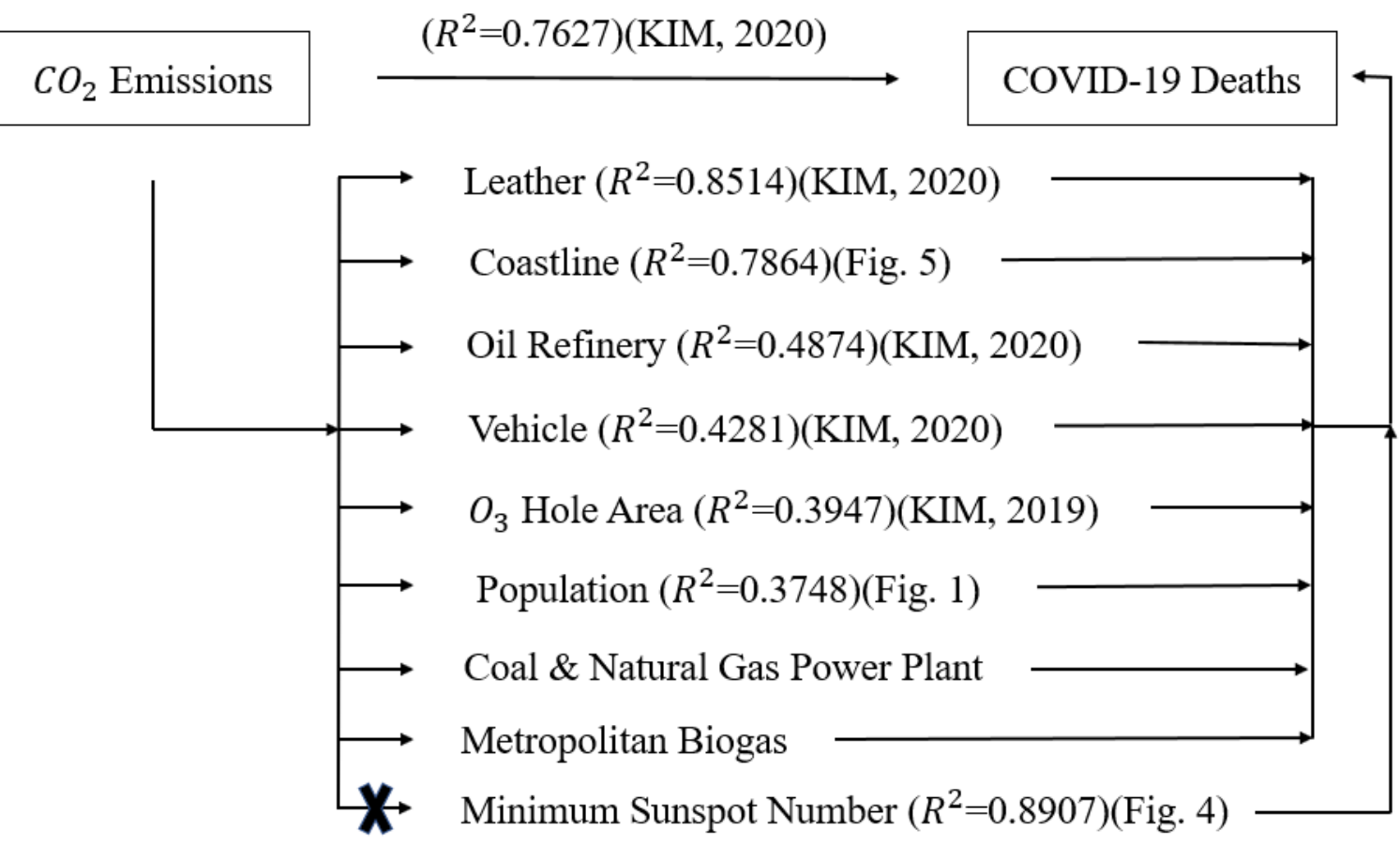

Table 1: $\mathrm{CO}_{2}$ emissions proportional to the COVID-19 deaths $\left(\mathrm{R}^{2}=0.7627\right)$, where the COVID-19 deaths originated from leather tanning industry $\left(R^{2}=0.8514\right)(K I M, 2020)$, population $\left(R^{2}=0.3748\right)($ Fig. 1$)$, coastline (cetaceans) $\left(R^{2}\right.$ 
$=0.7864)$ (Fig. 5), oil refineries $\left(R^{2}=0.4874\right)(K I M, 2020)$, vehicles $\left(R^{2}=0.4281\right)(K I M, 2020)$, coal- and natural gaspowered plants, and metropolitan biogas. The minimum sunspot number was proportional $\left(\mathrm{R}^{2}=0.8907\right)$ to theCOVID-19 (total confirmed cases) (Fig. 4) from July 2019 to July 2020, depending only on the 11-year cyclic sunspot number.

\section{d) Termination of COVID-19}

The breeding period of the whales is from December to April, while the feeding period is from May to September (or from June to October) (NOAA FISHERIES, 2015). The human incubation period is from 2-14 days to possible outliners 0-27 days (WORLDOMETER, 2020). Therefore, the termination of COVID-19 is expected in June (or July) with an additional one month of human incubation to May (or June). However, it takes another month for whale migration as described below: The blue whale typically swims at a speed of 14 miles or $22 \mathrm{~km}$ per hour (www.worldanimalfoundation.net). The migratory distance covered by gray whales along the Pacific Coast between the Bering Sea in Alaska and Baja California in Mexico is $5,551 \mathrm{~km}$. The migratory distance covered by humpback whales along the Atlantic Coast between the Dominican Republic and Greenland is $6,151 \mathrm{~km}$. Both distances can be approximated as 6,000 $\mathrm{km}$ divided by $22 \mathrm{~km}$ to have 272 hours or 12 days. Approximately one month is considered as the additional migratory period to June (or July) for July (or August) as the termination period of the COVID-19 pandemic in the USA.

The OFF SWITCH for termination of the COVID19 depends on the high sunspot number ( $>$ around 2550 ), which may require a few more months to pass beyond July (or August).Besides, Fig. 2A showed the bell distribution of the COVID-19 for the New York City from March to July with the peak on April 12, 2020, which took four months to be ON and OFFSWITCH of the COVID-19 distribution, respectively. Thus, two months later from July (or August) changes to September to November (or October to December)so that the sunspot number (SPACE WEATHER PREDICTION CENTER, 2020) may provide high sunspot number ( $>$ around 25-50), as observed in2018 for MERS-CoV (25) (KIM, 2019) and 2003 for AIV (50) (KIM, 2018), to possibly turn OFF SWITCH for the COVID-19 pandemic.

Ward (2019) and Sorace (2019) observed warning phenomena that 100 and 136 dolphins found dead on beach of Cape Verde (Site \# 2 of 14 humpback whale habitats) of West Africa in September 28 and 30, respectively, 2019. Two months later, there was the coronavirus (COVID-19) pandemic in Wuhan city of China, near to Site \#3 of Western North Pacific (KIM, 2019) onNovember17 of 2019 (WHO, 2020).

Similarly, new type of virus may appear in September of 2020 from the Poles either to 14 humpback whale habitats (KIM, 2020) or one of top 5 countries(BLOKHIN, 2019), creating most of the world's
$\mathrm{CO}_{2}$ emissions (China, United States, India, Russia, and Japan). There can be a competition of virus survival between the COVID-19 and the newly arrived virus at such locations for a few months so that the COVID-19 may competitively inhibit the new virus and fade away, as used to occur in toxic cyano bacteria in the lake (WATANABE, 1994). The OFF period occurs during the high sunspot number ( $>$ around 25-50) and may terminate COVID-19 in September (optimistic prediction) or in November 2020 (pessimistic one).

There were three typical cases of COVID-19 termination, based on the new daily reported cases coronavirus map and case count by the New York Times (July 29, 2020) as follows.

Case1 in Fig. 2A with bell curve decrease; NYCFig. 2A, Germany, U.K., Italy, Spain, France, Canada, USA (NYC, NJ, RI, NH, MD, MA, CT, AZ, UT, DC),

Case 2 in Fig. 2B with stepwise increase; Brazil, Mexico, India, Russia, Peru, Ecuador, Chile, Belgium, USA (CA- Fig. 2B, FL, NC, SC, GA, OR,TX, AL, ID, TN, WI, MI, MO, AR, KY, NV, NE, WY, AK, PR),

Case 3 in Fig. 2C with see-saw increase; Tokyo, Israel, USA (ME- Fig. 2C, VA, PA, DE, WA, CO, MI, IL, $V T$, LA, OH, IN, MN, IA, KS, WV, SD, ND, HI).

The maine parameters caused by the COVID-19 are; Case 1 could be the cetaceans, including whales, dolphins, and porpoises. Cetaceans began to migrate to the Poles in April and complete their journey in June, whose COVID-19 may last the shortest period till September2020. Case 2 could be the leather tannery industry, exporting hides to other countries, whose COVID-19 may last the middle period till October 2020. Case 3 for the mixed causes with multi sources such as leather tanning, cetaceans, oil refinery, vehicle, coaland gas-powered plants, whose COVID-19 may last the longest period till November 2020. The Maine one in Fig. $2 \mathrm{C}$ is the intermediate stopover of humpback whales from the Dominican Republic toward the final destination of the Arctic Ocean. Case 3 could cause by partly coming in from the breeding ground of the Dominican Republic and going out to the feeding ground of the Arctic Ocean. In general, the COVID-19 is in decreasing mode in Fig. 2. Furthermore, Fig. 4 displays the linear $\left(R^{2}=0.8907\right)$ increase of the minimum sunspot number (23 as of July 31, 2020) (SPACE WEATHER SERVICES, 2020) for turning OFFSWITCH (sunspot number $>$ around 25-50)for the COVID-19 pandemic. When sunspot increases, ozone concentration increases to decrease UV-B radiation $(\mathrm{NIH}, 1989)$ so that COVID-19 decreases to terminate. 


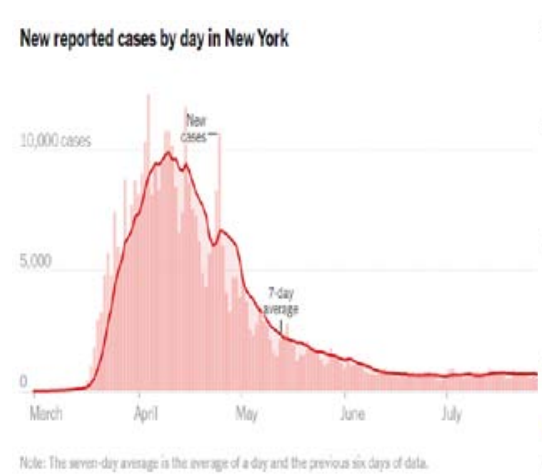

(A)

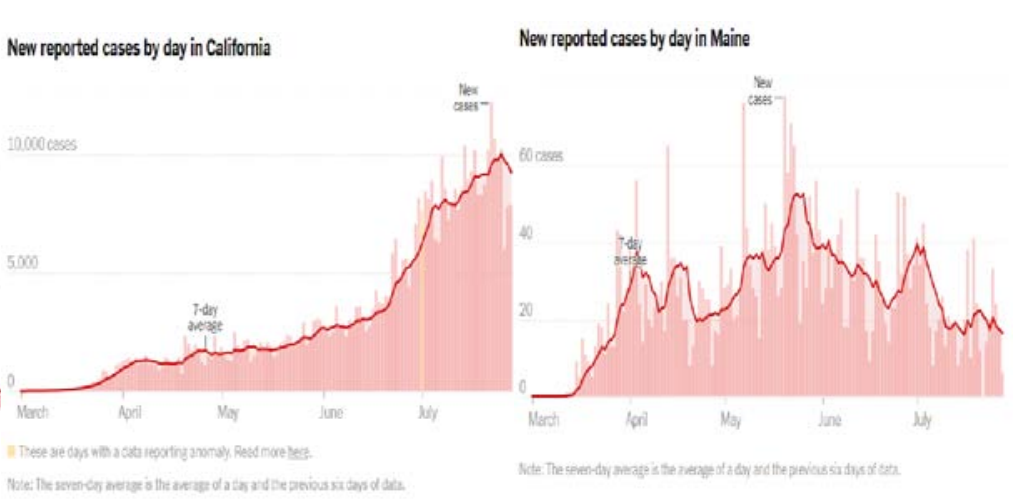

(B)

(C)

Figure 2: (A). for Case 1.Coronavirus maps and new reported cases by day in New York City, (B). for Case 2.California, and (C).for Case 3. Maine, by The New York Times (July 29, 2020).

Fig. 2 A describes the reported daily infections from March 1 to July 1 in New York City (New York Times, 2020), with a peak reached on April 12, 2020. New York City is on the migratory routes of humpback whales (Site \# 1 for New York City) (KIM, 2020). Fig. 2 implied that the humpback whales have begun to migrate from New York City (Fig. 2A) to the Baffin Bay/ Labrador Sea in the Arctic Ocean. The cases caused by the humpback whales may begin to decline as they swam from the breeding grounds (the Dominican Republic, \# 1), passing through Florida, Georgia, South Carolina, North Carolina, Virginia, Maryland, Delaware, Pennsylvania, New York, New Jersey, Connecticut, Massachusetts, New Hampshire, and Maine-Fig. 2C, to feeding grounds (Iceland, Labrador Sea, Baffin Bay, and the Arctic Ocean). The cases of the COVID-19 caused by the gray whales in the Pacific Coast (WOLFE, 2019), may begin to decline from the breeding grounds (Baja California of Mexico, \# 5), passing through California (Fig. 2B) (San Diego, Los Angeles, Point Piedras Blancas), Oregon (Depoe Bay), Washington (Seattle), Canada (Vancouver), and Alaska (Gulf of Alaska), to feeding grounds (Bering Sea, Chukchi Sea, and the Arctic Ocean).

\section{e) Personal Protection from COVID-19}

Japanese areas near volcanic regions were much safer than regions with no volcanoes in the vicinity in the section of III -y) Japan. Therefore, in non-volcanic countries, people can easily protect themselves from the COVID-19 by spraying small amounts of artificial volcanic gases such as $\mathrm{H}_{2} \mathrm{~S}$ and $\mathrm{SO}_{2}$, as shown in Equation (2). Hydrogen sulfide $\left(\mathrm{H}_{2} \mathrm{~S}\right)$ is a typical gas with duality for the COVID-19. Its anti-inflammatory responses in respiratory diseases studied by the $\mathrm{NIH}$ grant (CASOLA, 2018), which is applicable to cure the confirmed COVID-19 patients. The artificially rotten eggs can use to generate minor amounts of $\mathrm{H}_{2} \mathrm{~S}$ gas. Garlic compounds metabolize to $\mathrm{H}_{2} \mathrm{~S}$ (UNIVERSITY OF ALABAMA, 2007). A few easy preparation steps with volcanic gases can protect people from the COVID-19 as 1) Use rotten egg ( $\mathrm{KIM}, 2020)$ to generate minor amounts of $\mathrm{H}_{2} \mathrm{~S}$ indoors, 2)Eat a piece of garlic per day for minor generation of metabolic $\mathrm{H}_{2} \mathrm{~S}$, 3) Eat curcumin (HE et al.,2015)and garlic together as food to protect the respiratory systems from the COVID-19, 4) $\mathrm{SO}_{2}$ can prepare by putting sulfur (S) powder on the burning charcoal hotter than $500^{\circ} \mathrm{C}$. Such artificial volcanic gases of $\mathrm{H}_{2} \mathrm{~S}$ and $\mathrm{SO}_{2}$ are necessary indoors while keeping proper ventilation,5)Do not go outside for prevention of the COVID-19 when either negligible UV-B radiation (Fig. $3 \mathrm{~A})$ is available from the sunset to the next sunrise or the flower of Tradescantia closes (Fig. 3C). Since UV-B radiation disinfects the virus (KIM, 2019), it is necessary to go outside only during the daytime with potent UV-B radiation (Fig. 3A) or during the open flower period of Tradescantia (Fig. 3B), as a bio-indicator against the COVID-19, 6) Clean up the food waste as often as possible due to its harmful biogas (DUMONT, 2015), 7) Do not use the subway but use the bus with the sunlight and UV-B radiation, killing the virus (KIM, 2019), 8) Do not stay in the underground floors but in the upper floors with the sunlight to kill the COVID-19 by the solar UV-B radiation,9) Do not stand behind the running vehicle muffler with toxic gases, 10) Stay at the green region with forest and agricultural lands, 11) Stay within a tropic whose latitude is less than 20, and 12) Stay above Arctic Circle with latitude of66, for the powerful UV-B radiation killing the COVID-19.

The Korea Meteorological Administration at Ulsan city in South Korea showed a typical UV-B Index during the 24-hour variation in Fig. $3 \mathrm{~A}$ with the peak value at noon with minimal at both of the sunrise and the sunset, as of July 25, 2013. COVID-19 decreases as UV$B$ radiation increases (KIM, 2020). Tradescantia is exposed to low-level gamma rays and has linear relationship with the somatic mutation frequency (ICHIKAWA et al., 1981). The present work observed that Tradescantia (Fig. 3) opened its flower at dawn and closed at around $4 \mathrm{pm}$ till the next dawn. Tradescantia with open flower (Fig. 3B) as a bio-indicator, 
corresponded to a safe daytime due to potent UV-B radiation (Fig. 3A) acting against the COVID-19. On the other hand, the closed flower(Fig. 3C)during the insufficient UV-B radiation (Fig. 3A), indicated an unsafe period inducing the COVID-19.The flowering of Tradescantia was proportional to the UV-B radiation while the COVID-19 decreases as the UV-B radiation increases (KIM, 2020). It recommends not to stay outside for prevention of the COVID-19 pandemic when either UV-B radiation is negligible from the sunset to the next dawn (Fig. 3A) or the flower of Tradescantiac loses (Fig. 3C).

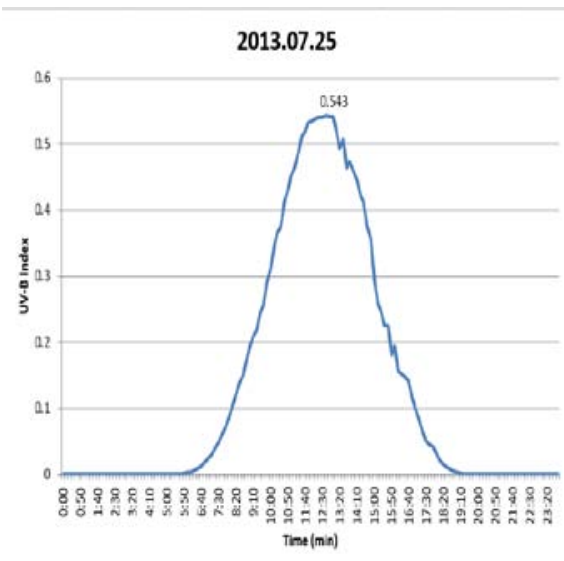

(A)

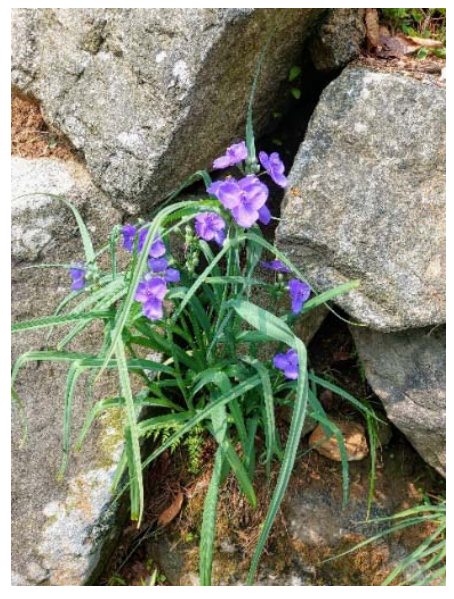

(B)

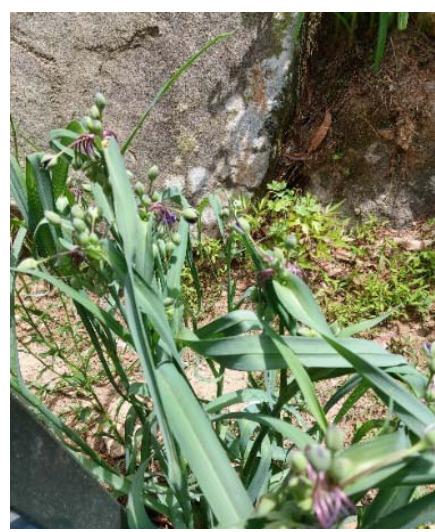

(C)

Figure 3: (A). UV-B Index from Korea Meteorological Administration at Ulsan city in South Korea showed the peak value at noon while minimal ones at both of the sunrise and the sunset during the 24-hour variation, as of July 25, 2013. (B). The open flower of Tradescantia, as a bio-indicator in the morning, indicated a safe environment with potent UV-B radiation against COVID-19. (C). A closed flower one in the late afternoon, with insufficient UV-B radiation, indicated an unsafe period inducing the COVID-19.

UV-B radiation (Fig. 3A) or UV-B radiator (KIM, 2019 ) is a simple tool to protect people from the COVID19. The installation of UV-B radiation, in the subway, undergrounds, churches, schools, hospitals, offices, homes, streetlamps, and drinking water, is necessary to kill all the viruses (KIM, 2019), including the COVID-19 pandemic.

The artificial volcanic gas $\left(\mathrm{H}_{2} \mathrm{~S}\right.$ or $\left.\mathrm{SO}_{2}\right)$ minimizes the COVID-19 casualties, as was the case in volcanic countries. The number of active volcanoes is shown in parenthesis, while the global rank of the COVID-19 for the 25 worst-hit countries is given as of July 2020: 1 . USA (169), 2. Brazil (0), 3. India (7), 4. Russia (12), 5. Peru (21), 6. Chile (3), 7. U.K. (0), 8. Mexico (48), 9. Spain (11), 10. Iran (14), 11. Italy (48), 12. Turkey (10), 16. France (13), 17. Germany (4), 20. Canada (5), 25. Sweden (0), 26. Indonesia (141), 29. Ecuador (27), 35. Philippines (23), 37. Netherlands (2), 44. Israel (0), 56. Japan (110), 64. South Korea (0). Most of volcanoes in the USA are in Alaska, Hawaii, and the Pacific Coast. Thus, the volcanoes in the USA did not contribute to the decrease of the COVID-19. On the other hand, Japanese volcanoes saved Japan, ranked 56th, from the crisis of the COVID-19, as shown in the section of III -y) Japan. The active volcanoes in volcanic countries such as 26. Indonesia (141), 29. Ecuador (27), 35. Philippines (23), and 37. Netherlands (2), showed the reduced casualties by the COVID-19, which is explained by the effect of volcanic gases in Equation (2).

\section{f) Sunspot Number}

UV-B causes skin cancer and suppresses the immune system. The thinning of the ozone layer (about $3 \mathrm{~mm}$ in thickness)over Antarctica caused by ozone depleting chemicals (CFCs)in eastern China (RIGBY, 2019). A significant viral mutation occurred in the period of the minimum sunspot number in a location with the highest $\mathrm{CO}_{2}$ emissions and ozone hole areas. As was the case with the COVID-19 outbreak from 2019 to the present August of 2020 in Wuhan of China, other large cities occurred in New York City, Madrid, Paris, London, Milan, Bavaria, Istanbul, Tehran, Tokyo, and 188 countries and regions.

The increases in $\mathrm{CO}_{2}, \mathrm{O}_{3}$ hole area, and UV-B caused the proportional increase with the COVID-19(R ${ }^{2}$ $=0.8064)(\mathrm{KIM}, 2020)$. The $\mathrm{O}_{3}$ hole area showed $\mathrm{a}$ reversely proportional relationship with the sunspot number $\left(R^{2}=0.2668\right)$ (KIM, 2020) while a linear relationship with $\mathrm{CO}_{2}$ emissions $\left(\mathrm{R}^{2}=0.3947\right)$ (KIM, 2019). Since the sunspot number begins to increase with time $\left(\mathrm{R}^{2}=0.8907\right)$ in Fig. 4, the $\mathrm{O}_{3}$ hole area, UV-B, and the COVID-19 began to decrease due to their reverse proportionalities with the sunspot number.

The sunspot number was as follows; July 2019 (sunspot number 0.7), August (0.7), September (0.8), October (0.7), November (0.8), December (1.9), January 2020 (5.9), February (0.4), March (1.2), April (4.8), May (0), June (5.9), July 4 (12), to July 31 (23). There was a linear relationship $\left(R^{2}=0.8907\right)$ between total 
coronavirus (COVID-19) cases and the sunspot number (SPACE WEATHER PREDICTION CENTER, 2020) from July 2019 to July 2020, as shown in Fig. 4.

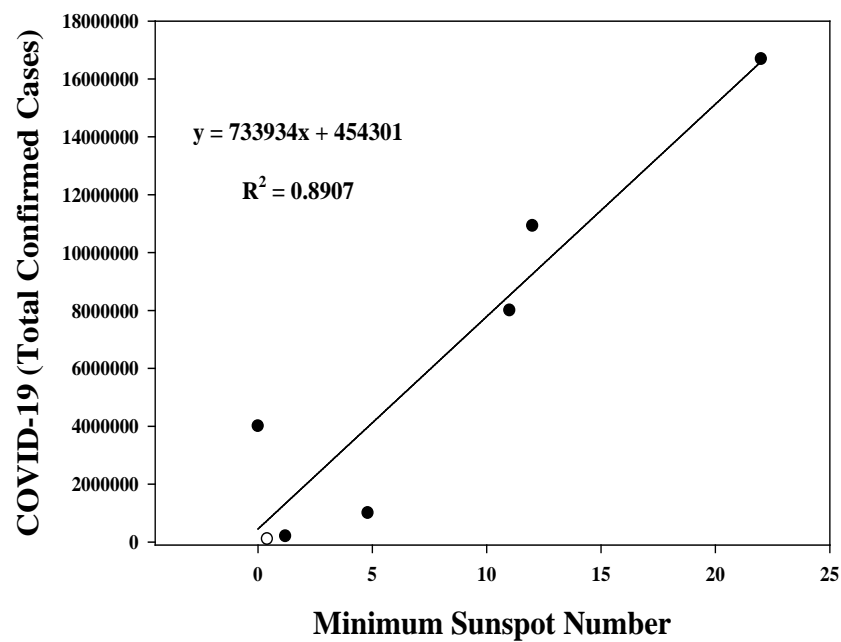

Figure 4: Linear relationship $\left(R^{2}=0.8907\right)$ of total coronavirus confirmed cases with the minimum sunspot number from July 2019 to July 2020.

The COVID-19 pandemic began in November 2019 in Wuhan of China with a sunspot number of 2(SPACE WEATHER SERVICES, 2020) as ON SWITCH mechanism for the COVID-19. OFF SWITCH mechanism for terminating the COVID-19 pandemic began to increase the minimum sunspot number from 23 as of July 31, 2020 to around 25-50 in the future. Previous sunspot numbers for the OFF SWITCH mechanism were 50 for AIV in 2003 (KIM, 2018) and 25 for MERS-CoV in 2018 (KIM, 2019). During the minimum sunspot number, UV-B is so strong that the virus in the Poles changes into the dangerous mutant virus, carried by migratory birds (H1N1, 2008)(KIM, 2018) orhumpback whales for AIV (KIM, 2018) and COVID-19 (KIM, 2020). The years of 2019-2020 fall within the period of the minimum sunspot number, showing significant linearity with the previous works about AIV outbreaks $\left(R^{2}=0.9967\right)(K I M, 2018)$, humpback whale stranding $\left(R^{2}=0.6128\right)(K I M, 2018)$, record low temperatures in Chicago $\left(R^{2}=0.9995\right)$ and $\mathrm{La}$ Nina Index $\left(R^{2}=0.9922\right)(K I M, 2019)$, and the COVID-19 (total confirmed cases) $\left(R^{2}=0.8917\right)$ in Fig. 4.

The present study proposes that the sunspot number is analogous to a SWITCH, turning an epidemic ON and OFF 11-year cyclic virus from the Poles to the Continents with TRANSITION state inducing a publichealth crisis such as,

1) $\mathrm{ON}$ SWITCH mechanism during minimum (maximum) sunspot number in the parenthesis and high UV-B radiation, emerges the mutant virus from the Poles to the Continents, transmitted by migratory birds (KIM, 2018) and humpback whales for 2002 SARS (125) and 2012 MERS-CoV(110) (KIM, 2019) during maximum sunspot number. During minimum sunspot number (KIM, 2019), there were 1966 Hong Kong Flu(0), 1976 Ebola (14), 1985AIV-Victoria (18), 1996 H5N1AIV (8), 2008 H1N1pandemic (4) (SOLAR DYNAMICS OBSERVATORY, 2008), and 2019 COVID19pandemic (2)(SPACE WEATHER SERVICES, 2020).

2) OFF SWITCH mechanism during high sunspot number (> 25-50) for possible termination of the COVID-19 pandemic, which switched ON in Wuhan in China under minimum sunspot number (2)(SPACE WEATHER SERVICES, 2020),

3) OFF SWITCH mechanism during low sunspot number for terminations of 2003 SARS (80) and 2018 MERS-CoV (25), which switched ON under the maximum sunspot number for SARS (125) and MERS-CoV (110) (KIM, 2019),

4) TRANSITION state $(0<$ Sunspot Number $<25-50)$ to become the public-health crisis, as was the case in the COVID-19 pandemic.

The minimum sunspot number (COVID-19 pandemic $(713,845$ deaths as of August 7,2020$)$ caused much more strong casualties than those during the maximum sunspot number of 774 SARS and858MERS-CoV.

During the sunspot number of the11-year cycle with 14 months of standard deviation (HATAWAY, 2010), there are always maximum or minimum points of the sunspot number. In each case, there can be ON, Transition, and OFFSWITCH mechanisms. Major casualty expects during transition period.

Once turned ON SWITCH(emergence of the epidemic) by either minimum sunspot number or maximum sunspot number, causing virus mutation in the Poles during the potent UV-B radiation under the 
highest $\mathrm{CO}_{2}$ emissions, it is impossible to turn OFF SWITCH(termination of the epidemic) intentionally until turned OFF by global environments. $\mathrm{CO}_{2}$ emissions increase continuously over the years $\left(R^{2}=0.9497\right)$. The ozone absorbs solar UV radiation to decrease the UV-B $(\mathrm{NIH}, 1989) . \mathrm{CO}_{2}$ emissions were proportional $\left(\mathrm{R}^{2}=\right.$ 0.4116 ) to the ozone hole area, and thus, $\mathrm{CO}_{2}$ emissions lead to powerful UV-B radiation on the Earth (KIM, 2019).

The sunspot number is controlled by the Sun, while the solar radiation on the Earth can minimize by the reduction of global $\mathrm{CO}_{2}$ emissions. It is thus necessary not to turn ON SWITCH of the sunspot number for minimization of the11-year cyclic epidemic. The reduction of global $\mathrm{CO}_{2}$ emissions should follow in the areas of the leather tanning industry, oil refineries, vehicles, coal- and gas-powered plants, population, and metropolitan food waste gas.

\section{g) Coastline}

It postulated that cetaceans, including whales, dolphins, and porpoises, that swim off coastlines globally, were a contributory factor in inducing the COVID-19 disaster in over 188 countries and regions (KIM, 2020). Infected humpback whales might be the reservoir of the cetacean morbillivirus (CMV) in the form of infected feces (KIM, 2020) through their migratory behaviors (JO et al., 2018). Released feces infected porpoises and dolphinsin the 14 humpback whale districts (KIM, 2020), including the Yangtze River and East Sea (Site \# 3 among 14 habitats) being then evolutionally transmitted to humans in Wuhan in China as COVID-19 (KIM, 2019). The sudden spread of the coronavirus could be traced to the 14 habitats of humpback whales, linked to millions of dolphins (KIM, 2020). Coastline data in $\mathrm{km}$ is available from Field Listing-Coastline (CIA, 2020). COVID-19 deaths, as of June 18, 2020, are in parenthesis for the top 15 countries hit by COVID-19; USA 19,924 km $(117,694)$, Brazil 7,491 km (46,510), U.K. 12,429 km $(42,238)$, Italy $7,600 \mathrm{~km}(34,448)$, France 4,853 km (29,578), Spain 4,964 km (27,136), Mexico 9,330 km (18,310), India $7,000 \mathrm{~km}(11,903)$, Belgium $66.5 \mathrm{~km}(9,675)$, Iran 2,440 km (9,185), Germany 2,389 km (8,851), Canada 202,080 km $(8,312)$, Russia $37,653 \mathrm{~km}(7,468)$, Peru 2,414 km $(7,257)$, and Netherlands $451 \mathrm{~km}(6,093)$. Fig. 5 shows that the coastline of each country is proportional $\left(R^{2}=\right.$ 0.7864) to COVID-19 deaths. Countries with very long coastlines along the Arctic such as Russia and Canada excluded from the correlation. At the same time, countries with very short coastlines such as Belgium and Netherlands also excluded in Fig. 5. It is therefore clear that dolphins and humpback whales spread COVID-19 around the world while swimming at the coastlines of each country.

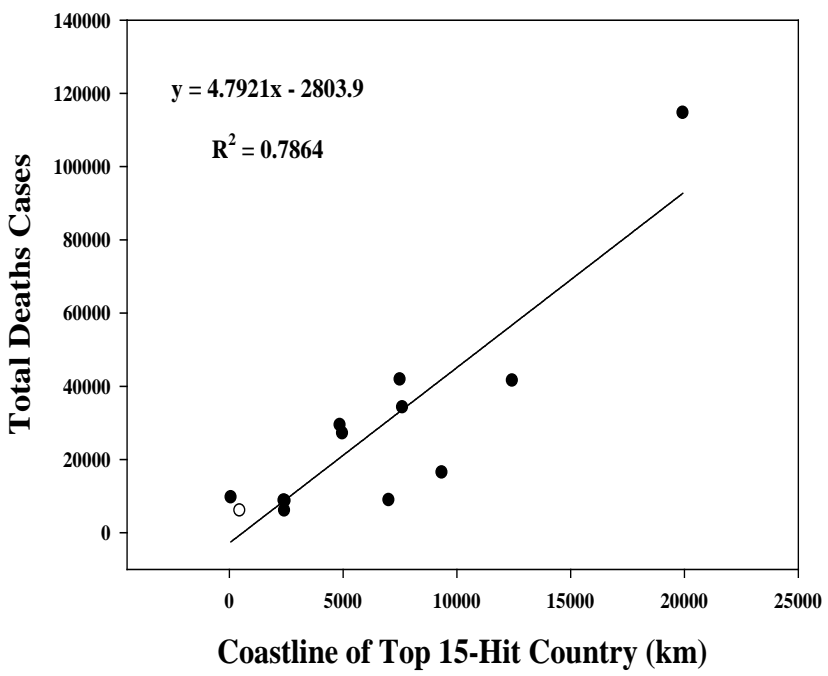

Figure 5: Coastline of 15 countries hit by the coronavirus (COVID-19) was proportional $\left(R^{2}=0.7864\right)$ to the COVID19 deaths, showing the importance of the coastline, where cetaceans swim in shallow (25 ft) water.

\section{ili. Case Studies}

a) USA

The USA ranked second globally for $\mathrm{CO}_{2}$ emissions $\left(5,269 \mathrm{Mt} \mathrm{CO}_{2}\right)$ and has a population of 325.1 million in 2017 (FROHLICH, 2019). $\mathrm{CO}_{2}$ emissions produced by coal- and gas-powered plants, oil refineries, vehicle exhaust gas, metropolitan food waste gas, human exhalation, leather-tannery industry, and the organic dye industry. The coastline of the USA is 19,924
$\mathrm{km}(\mathrm{CIA}, 2020)$.Fig. 6 shows that the coastline of each country is proportional $\left(R^{2}=0.3099\right)$ to COVID-19 deaths. Since cetacean morbillivirus (CMV) induced the coronavirus (COVID-19) pandemic (KIM, 2019), the Pacific Coast and the Atlantic Coast of the USA were also open to the danger of the COVID-19. There are 169 volcanoes in the USA. The USA has $264,194,000$ registered vehicles. The latitude of the USA is $38^{\circ} \mathrm{N}$ and thus an unsafe zone from the COVID-19. 


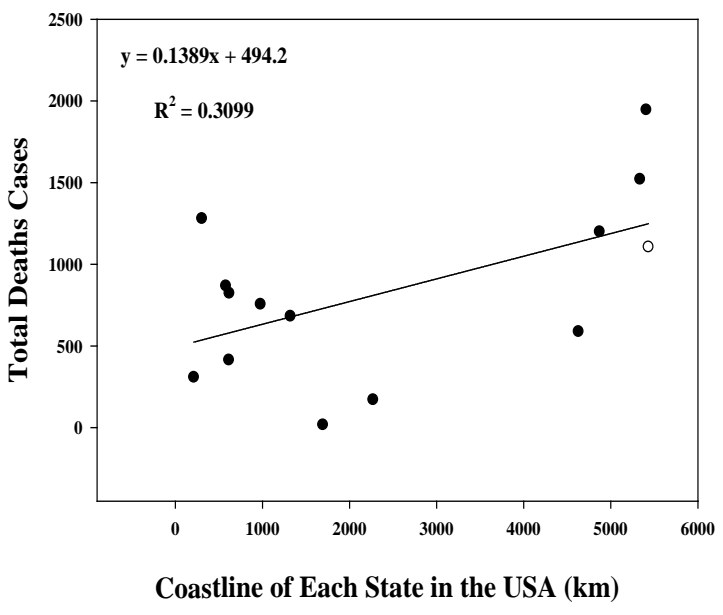

Figure 6: The coastline of each state in the USA is proportional $\left(R^{2}=0.3099\right)$ to the COVID-19 deaths case.

Leather is a multi-billiondollar global industry with criticism of its severe environmental impact (LEATHER PRODUCTION SUSTAINABILITY, 2018). Chemicals from the leather tanning industry and organic pigments in tannery wastewater, caused soil and water pollution, resulting in dangerous health hazards to both humans and animal life(SAXENA et al., 2016). Chemicals from the leather industry and organic pigments pollute freshwater in rivers and lakes such as the Mohawk River; Hudson River (New York), Mississippi River (Minnesota (20), Wisconsin (25), lowa (24), Illinois (4), Missouri (29), Kentucky (33), Tennessee (19), Arkansas (32), Mississippi (26), Louisiana (13), Los Angeles River (CA (3)), Colorado River (Colorado (21), Arizona (18), California (3)), and New York (1). Lakes; Erie, Ontario, Oneida, Seneca, Cayuga (New York (1)), Lake Michigan (Wisconsin (25), Illinois (4), Indiana (17), and Michigan (9)). The parenthesis numbers are the
State rank of the COVID-19deaths, as of June 18, 2020. Milwaukee's leather industry had a tremendous impact on the city's environment, polluting Milwaukee's rivers as well as Lake Michigan with industrial chemicals (WALZER, 2016) (https://emke.uwm.edu/entry/leatherindustry/). There are 111 leather tanning facilities in the USA, and the Northeast and Midwest states; Pennsylvania (9), Massachusetts (7), New York (1), and Wisconsin (21) have almost half of the facilities (MAX, 2018).In Gloversville, New York, the former old leather tannery (Fig. 7A) poses a threat to public health and welfare. Since it still contains toxic chemicals, the facility should be demolished thoroughly not to contaminate the Hudson River, which is the main river in the region, passing through New York City and New Jersey State (Fig. 7B). Those metropolitan areas were the first and second most hit regions by COVID-19 in the USA.
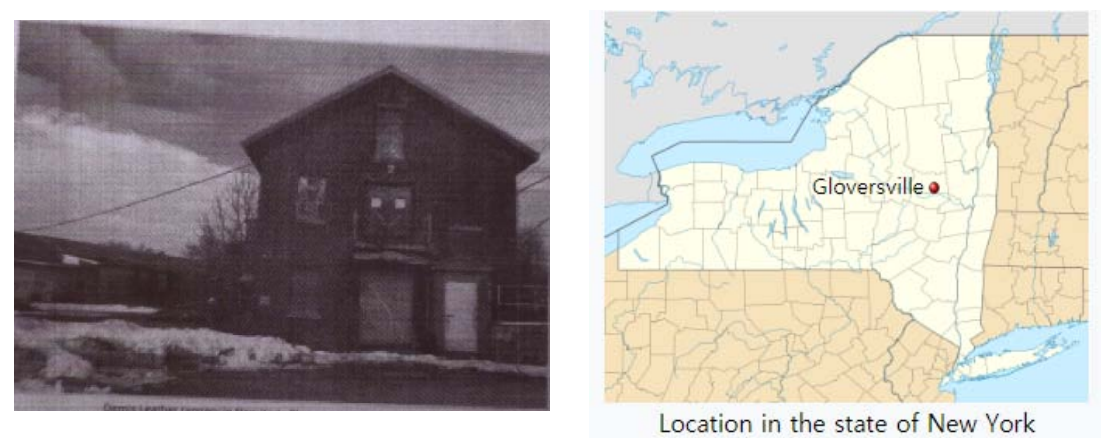

Figure 7: (A) Old tannery in NY. (B) Gloversville in NY, connected with Hudson River.

Recently California (3), Michigan (9), Illinois (4), Ohio (16), have leather tanning facilities while the numbering in parentheses is the rank of coronavirus cases as of June 18, 2020.The leather industry has polluted the water and the air causing the spread of the coronavirus in the USA. Typical tannery industry chemicals that contain246 hazardous agents might have deteriorated the water of the Hudson River and have emitted toxic gases $\left(\mathrm{NH}_{3}, \mathrm{H}_{2} \mathrm{~S}\right.$ and carcinogenic arylamines) into the air (ECOPOL-Home, 2020) (https://leathersustainability.weebly.com/). This tannery might pollute the Hudson River with toxic chemicals that 
could have caused New York $(31,046)$ and New Jersey $(12,891)$ deaths (as of June 18, 2020). Other causes of death could be the stack gases from 6 oil refineries in New Jersey, flue gases from 3 natural gas-powered plants in New York, two coal-powered plants, and ten gas-powered plants in New Jersey. Flue gas from power plants and stack gas from oil refineries emit toxic gases $\left(\mathrm{SO}_{2}, \mathrm{CO}_{2}, \mathrm{NOx}, \mathrm{H}_{2} \mathrm{~S}\right)$. Dolphins in the Hudson River and whales in the Atlantic Coast could also transmit the coronavirus causing the deaths of residents in New York Harbor and New Jersey. Also, metropolitan people and vehicles produce high $\mathrm{CO}_{2}$ emissions in New York City, increasing the number of deaths. The decline of the glove industry meant people left the city, so old tanneries were still left or abandoned (Fig. 7A). The effluents from the abandoned tanneries with toxic residual chemicals flow into the Mohawk River, which is the largest tributary of the Hudson River (Fig. 7B). New York State capital Albany, locates where the Mohawk and Hudson Rivers converge. Albany, in the upper stream of the Hudson River, had 108 deaths, while New York City, farther downstream, had 21,856 deaths. In the Atlantic Ocean, New Jersey had 15,057 deaths and Connecticut 4,307 deaths, as of June 27, 2020. Since New York City, New Jersey, and Connecticut are on the Atlantic Coast, dolphins might transmit the coronavirus to these coastal states.

There are 161 volcanoes (USGS, 2020): 18 very high threat, 39 high threat, 49 moderate threat, 34 low threat, and 21 very low threat volcanoes. The volcanoes are in Alaska (50), Arizona (18), California (3), Colorado (21), Hawaii (49), Idaho (43), Nevada (34), New Mexico (37), Oregon (40), Utah (31), Washington (22), and Wyoming (48). The states with volcanoes were shown to be under little threat, as of June 18, 2020, except California, Washington, and Colorado. Numberings of power plants and oil refineries are indicated in parenthesis in California (30), Washington (5), and Colorado (57), with toxic gases in the flue gas from power plants and in the stack gas from oil refineries. The total amount of inhaling rate of $(\dot{\mathrm{M}})$ of volcanic gas $\left(\mathrm{CO}_{2}\right.$, $\mathrm{H}_{2} \mathrm{O}, \mathrm{H}_{2} \mathrm{~S}, \mathrm{H}_{2} \mathrm{SO}_{4}, \mathrm{SO}_{2}, \mathrm{HCl}, \mathrm{HF}$, particulate matter) relates with volcanic gas concentration (C), human inhaling volume rate $\left(V=8\right.$ liter $\left./ \mathrm{min}=8,000 \mathrm{~cm}^{3} / \mathrm{min}\right)$, and exposuretime $(\Delta t)$ as Equation (1),

$$
\dot{\mathrm{M}}=\mathrm{CV} \Delta \mathrm{t}
$$

There are dual behaviors of volcanic gas and toxic gas, the latter originated from leather tanning industry, oil refinery stack gas, coal-powered and natural gas-powered flue gases, vehicle, population, and metropolitan biogas, associated with the coronavirus (COVID-19) pandemic as follows:

CASE 1. Prevention of the coronavirus (COVID-19) pandemic by shielding volcanic gases with a low amount of inhalation rate $(\dot{\mathrm{M}} \downarrow)$, low gas concentration $(C \downarrow)$,for short-term acute exposure $(\Delta t \downarrow)$. The coronavirus activity inhibited by the toxic volcanic gas, as shown in volcanic countries and regions in Sicily in Italy, Kyushu in Japan, Philippines, Indonesia, Taiwan, and Alaska.

$$
(\dot{\mathrm{M}} \downarrow)=(\mathrm{C} \downarrow) \vee(\Delta t \downarrow)-\cdots-
$$

Minor amounts $(\dot{\mathrm{M}} \downarrow)$ of gases in CASE 1 protect people from the coronavirus (COVID-19), shown in Equation (2). Therefore, in non-volcanic countries, people can easily protect themselves from the coronavirus (COVID-19) pandemic by spraying small amounts of artificial volcanic gases such as $\mathrm{H}_{2} \mathrm{SorSO}_{2}$.

CASE 2. Casualties suffering from ahighinhalation rate $(\dot{\mathrm{M}} \uparrow)$ have their respiratory systems damaged by toxic gas from the leather tanning industry, oil refinery stack gas, coal-powered and natural gas-powered flue gases, vehicle, population, and metropolitan biogas. Case 2 is in a high concentration( $\mathrm{C} \uparrow$ ) for long-term exposure $(\Delta t \uparrow)$. This leads to a high number of the coronavirus (COVID-19) pandemic deaths forolder adults, as observed in Lombardy in Italy, Wuhan in China, New York City in the USA, Tokyo in Japan, Teheran in Iran, Daegu in South Korea, as shown in Equation (3).

$$
(\dot{\mathrm{M}} \uparrow)=(\mathrm{C} \uparrow) \mathrm{V}(\Delta \mathrm{t} \uparrow) \quad \ldots
$$

Vehicle exhaust emissions create when the airfuel mixture burning inside internal combustion engines releases carbon dioxide back into the atmosphere, causing health problems (AZO CLEANTECH, 2019). The composition of exhaust gases is $\mathrm{N}_{2}, \mathrm{O}_{2}, \mathrm{H}_{2} \mathrm{O}, \mathrm{CO}, \mathrm{CO}_{2}$, $\mathrm{NO}_{x}, \mathrm{SO}_{2}$, benzene, aldehydes, $\mathrm{O}_{3}$, particular matter (SKYBRARY, 2017).The relationship between vehicle numbers and $\mathrm{CO}_{2}$ emissions was linear $\left(\mathrm{R}^{2}=0.6313\right)$. The vehicles of the USA in 2018 amounted to279.1 millionunits.

The power plants of the United States are nuclear $(9.0 \%)$, hydro $(9.1 \%)$, wind and solar (13.5\%), coal (20.7\%), and natural gas (43.2\%) (BLUEGOLD RESEARCH, 2020). Flue gases contain harmful substances such as particulate matter, phenol, furfural, glycols, $\mathrm{H}_{2} \mathrm{~S}, \mathrm{NH}_{3}, \mathrm{C}_{6} \mathrm{H}_{6}, \mathrm{NaOH}, \mathrm{H}_{2} \mathrm{SO}_{4}, \mathrm{HCl}, \mathrm{HF}, \mathrm{SO}_{2}$, $\mathrm{NO}_{x}, \mathrm{CO}$, heavy metals, and harmful chemicals (GIUGLIANO et al., 2016). One hundred thirty-five petroleum refineries in the USA (2019) were shown in Fig.8A with 2 units in NJ (2), 18 in CA (3), 4 in IL (4), 13 in PA (7), 12 in Ml (9), 16 in FL (8), 47 in TX (6), 19 in LA (13), 18 in $\mathrm{OH}$ (16), 5 in WA (22), 15 in GA (11), and 12 in IN (17). The numberings in the parenthesis are the state rank of total COVID-19 cases in the USA, as of June 18, 2020. It is clear that 135 petroleum refineries in the USA are critical to cause the coronavirus (COVID-19) pandemic deaths $\left(R^{2}=0.4874\right)$.

Mapping how the United States generates its electricity showed in Fig. 8B while the distribution map 
of coronavirus (COVID-19) cases in the USA was in Fig.8C. The high deaths by the COVID-19 as of May 23,
2020, were in the order as follows NY, NJ, MA, CA, IL, $\mathrm{PA}, \mathrm{MI}, \mathrm{CT}, \mathrm{TX}, \mathrm{LA}, \mathrm{MD}, \mathrm{OH}, \mathrm{WA}, \mathrm{GA}$, and IN.

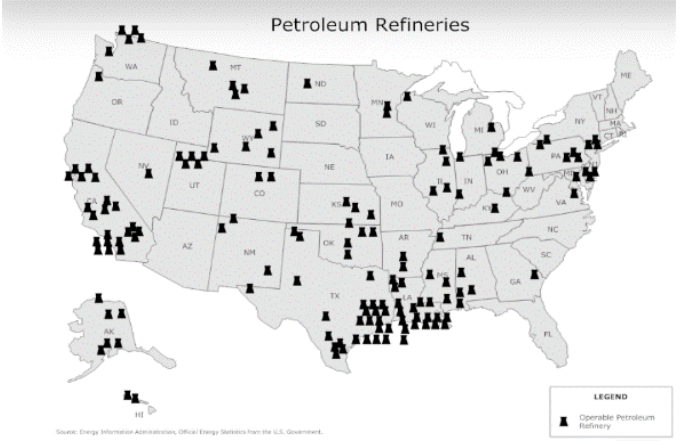

(A)

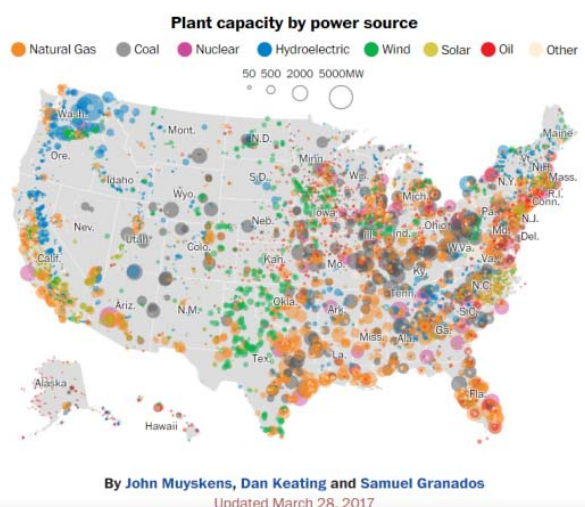

(B)

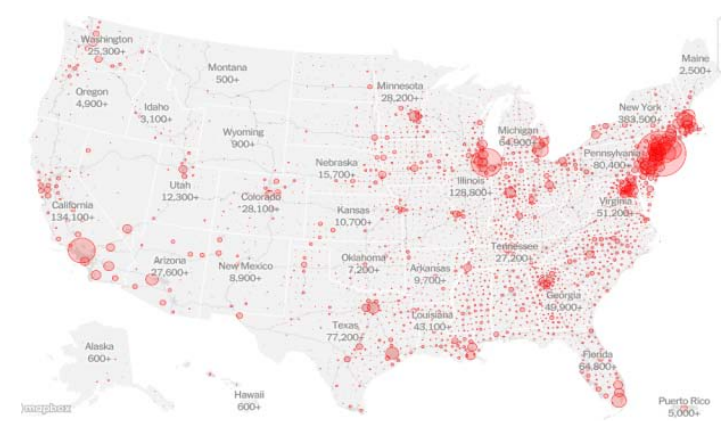

(C)

Figure 8: (A).Petroleum refineries map of the USA (Smart Draw).(B). Mapping how the United States generated its electricity in 2017 (John Muyskens, Dan Keating and Samuel Granados).(C). Distribution map of coronavirus (COVID19) cases in the USA (The New York Times).

Natural gas- and coal-power plants produce main pollutions. Petroleum refineries (Fig.8A) with toxic stack gas (CO, $\mathrm{SO}_{2}, \mathrm{O}_{3}, \mathrm{H}_{2} \mathrm{~S}, \mathrm{NO}_{x}$, caustic soda), supply petroleum and gas to power plants, while nonrenewable power plants(Fig. 8B)produce toxic flue gas $\left(\mathrm{SO}_{2}, \mathrm{H}_{2} \mathrm{~S}, \mathrm{O}_{2}, \mathrm{HF}, \mathrm{MRL}, \mathrm{CO}_{2}, \mathrm{CO}, \mathrm{NO}_{x}\right.$, lead, cadmium, particulate matter). The distribution of the coronavirus (COVID-19) pandemic in the USA was shown in Fig.8C, the distribution of, which overlapped with refineries in Fig. 8A and non-renewable power plants in Fig. 8B.It can partially conclude that pollution of air and water caused by oil refineries and non-renewable power plants contributed to the coronavirus (COVID-19) pandemic in the USA. Majorly hit-states by the coronavirus in each region are listed below. Eastern part is New York City/ New York (1) and New Jersey (2)as the origin of Eastern COVID-19 in the USA, including Massachusetts (5), Pennsylvania (7), Maryland (10), Connecticut (15), and District of Columbia (38). The western part is California (3), Arizona (18), and Washington (22).The southern is Texas (6), Florida (8), Georgia (11), Virginia (12), Louisiana (13), and North Carolina (14). The middle is Illinois (4), Tennessee (19), Minnesota (20), and
Colorado (21). The numberings in the parenthesis are the state rank of total COVID-19 cases in the USA, as of June 18, 2020.

The year of the avian influenza virus (AIV) outbreak was proportional to the year of minimal sunspot number from 1878 to 2016 with high linearity $\left(R^{2}=0.9967\right)(K I M, 2018)$. AlV cases(FULLER et al., 2010)along the Atlantic Coast of the USA plotted to $\mathrm{CO}_{2}$ emissions with $R^{2}=0.2911(\mathrm{KIM}, 2018)$. AIV cases plotted to the total coronavirus cases $\left(R^{2}=0.3793\right)$ in Fig. 9A and death cases $\left(R^{2}=0.4275\right)$ in Fig. 9B in the USA (as of June 18,2020$)$. 

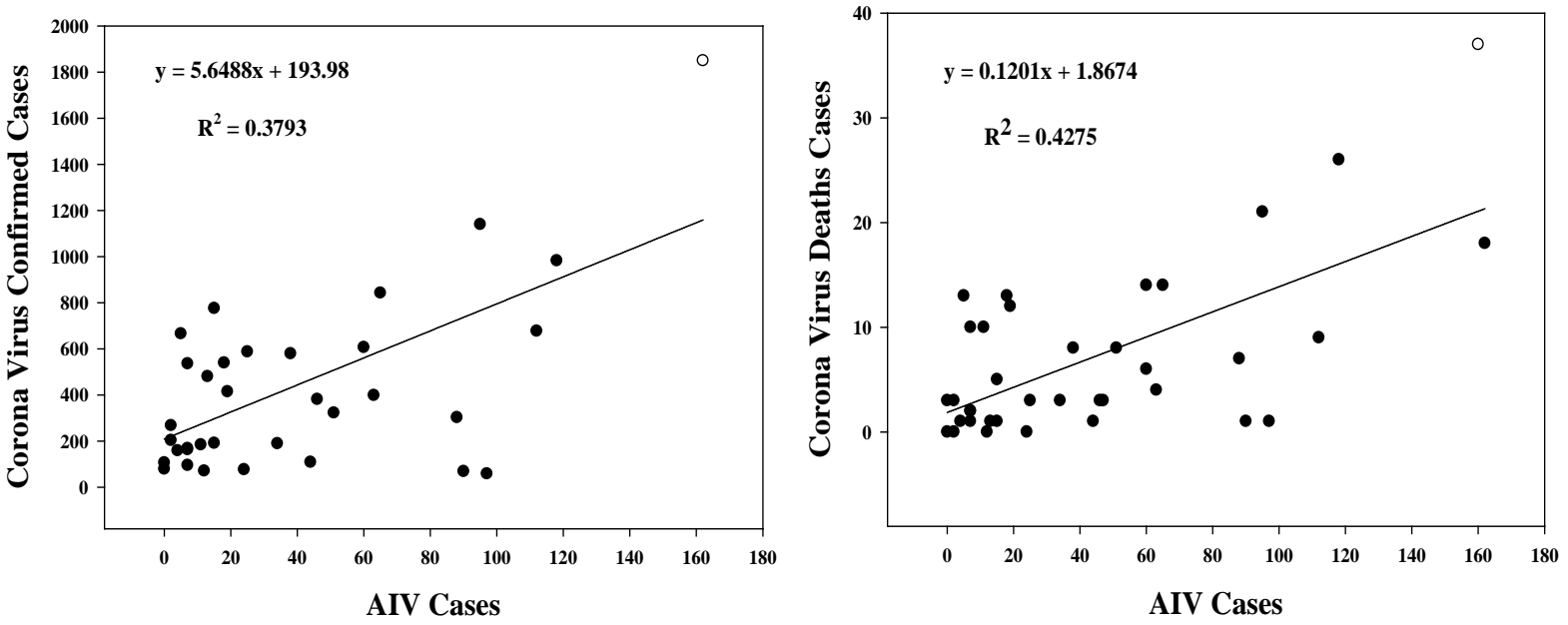

Figure 9: AlV cases (FULLER et al., 2010) plotted to. (A). coronavirus total cases $\left(R^{2}=0.3793\right)$ and(B). coronavirus total death cases $\left(R^{2}=0.4275\right)$ in the USA (as of June 18,2020$)$.

Fig. 9 implies that AIV cases (FULLER et al., 2010) relate with coronavirus total $\left(R^{2}=0.3793\right)$ and coronavirus total deaths $\left(R^{2}=0.4275\right)$ in the USA (as of June 18, 2020). During the period of the minimum sunspot number, AIV was carried by migratory birds in 2008 (KIM, 2018), and COVID-19 was carried by cetaceans in 2020 in the USA (KIM, 2020). Migratory birds and cetaceans (dolphin, porpoises, whales) are the transmitters inducing the coronavirus (COVID-19) pandemic, not only in the United States but also in the world where migratory birds and cetaceans travel (KIM, 2020).

The state of Wyoming is a vast plateau divided by mountain ranges such as the Rocky Mountains, at the base of which lie the Great Plains. As for the coronavirus (COVID-19), Wyoming ranks last with the lowest number of deaths (36) /1M population as of July10,2020. The USA surrounds by the Pacific Coast, Atlantic Coast, and Caribbean Sea with whales and dolphins, which carried CMV, which the evolutionarily changed into the coronavirus (COVID-19) in Wuhan in China (KIM, 2019). The migratory birds flyover the USA, spreading AIV (1996 H5N1, 2008 H1N1) during the minimum sunspot number. There are toxic gases from power plants, oil refineries, leather-tannery processes, textile industry, vehicle exhaust, metropolitan food waste biogas, and human exhalation gas. The virus mutates to cause diseases in humans, poultry, and animals. Viral activity enhances during the minimal sunspot number, as is the case in 2020 with an 11-year cycle. The USA was the country most affected by the coronavirus (COVID-19) in 2020. As for data of Deaths/1M pop (death per million of the population), New York $(1,664)$, California (174), Texas (108), Florida (191), New Jersey $(1,751)$, Illinois (580), Arizona (286), Georgia (279), Massachusetts (1,204), Pennsylvania (542), North Carolina (144), Michigan, (629), Louisiana (728),
Maryland (546), Virginia (229), Ohio (260), Tennessee (106), South Carolina (180), Alabama (225), Indiana (408), Connecticut (1,220), Rhode Island (921), Delaware (531), and District of Columbia (805), showed a significant number of deaths compared to those of other states. These hit states showed the common features such as 1)Along the coastline for cetacean transmission (Fig. 6), 2) Regions of the leather tanning (Fig. 7), 3) Areas of oil refineries (Fig. 8A), 4) Regions of natural gas- and coal-powered plants (Fig. 8B), 5)Metropolitan areas (Fig. 8C), all of which producing $\mathrm{CO}_{2}$ emissions for the coronavirus (COVID-19) pandemic.

If bad air- $\mathrm{CO}_{2}$ in New York City is replaced with good air- $\mathrm{O}_{2}$ in Wyoming State, the ozone hole in New York City may decrease with less UV-B radiation, as explained by $\mathrm{NIH}$ (1989). Therefore, compressed air with better air- $\mathrm{O}_{2}$ and less bad air- $\mathrm{CO}_{2}$ in Wyoming State would inhibit the viral activity of the coronavirus (COVID19)in metropolitan areas. Forest cover percentage of each state shows in the parenthesis with the COVID-19 deaths as follows: GA(67)- 3,168 deaths as of May 28, 2020, NY(63)- 32,490, MA(61)- 8,419, PA(59)- 7,022, $\mathrm{MI}(56)-6,366, \quad \mathrm{CT}(55)-4,396, \quad \mathrm{LA}(53)-3,543, \quad \mathrm{FL}(51)-$ 4,981, WA(44)- 1,444, NJ(42)- 15,706, MD(39)- 3,377, TX(37)- 3,939, DC(34)- 460, CA(33)- 7,702, OH(31)$3,173, \operatorname{IN}(21)-2,821$, and $\mathrm{IL}(14)-7,488$. The recovery from theCOVID-19 expects to start from the earliest states of Georgia and New York with high forest cover percentage eventually extending to Indiana and Illinois with low forest cover percentage. The key parameters causing the COVID-19 in the USA may be the leather tanning industry, cetaceans along the long coastline, and toxic gases from oil refineries, coal- and gaspowered plants, vehicles, population, and metropolitan food waste. The USA ranked first globally for coronavirus (COVID-19) deaths $(132,291)$ as of July 10 , 2020. 


\section{b) Brazil}

Brazil ranked 13th globally forCO $\mathrm{O}_{2}$ emissions (476.1 Mt $\mathrm{CO}_{2}$ ). $\mathrm{CO}_{2}$ emissions produced by 22 coaland6 gas-powered plants, 17 oil refineries, 42,743,000 registered vehicles' exhaust gases, metropolitan food waste gas, human exhalation with a population of 209.3 million, leather-tannery industry, and organic dye industry. The Brazilian coastline extends $7,491 \mathrm{~km}$ to induce the coronavirus (COVID-19) through dolphins and humpback whales (Site \#7 Brazil) (KIM, 2020). There is no active volcano. The latitude is $11^{\circ} \mathrm{S}$ and thus within the safe zone from the COVID-19. However, Brazil exports the leather tanning industry, causing pollutions in water as well as in air, leading to the spread of the COVID-19. Brazil ranked 2nd globally for coronavirus (COVID-19) deaths $(69,184)$ as of July 10,2020 , even though it locates at a safe latitude.

\section{c) India}

The coastline is $7,000 \mathrm{~km}$ with 7 volcanoes. The latitude is $21^{\circ} \mathrm{N}$ and thus near the safe latitude range. India ranked 3rd globally for $\mathrm{CO}_{2}$ emissions $(2,466.8 \mathrm{Mt}$ $\mathrm{CO}_{2}$ ) and has a population of 1,340 million. India has 28,860,000 registered vehicles, 23 oil refineries, 24 coalbased power stations (57\%), and gas power stations (7\%) with disastrous air pollution. India is the fifth biggest exporter of leather goods in the world. The leather industry in India accounts for $13 \%$ of the world's leather production, 9\% of the world's and 2nd largest footwear production with $20 \%$ of the world's cattle and buffalo, and $11 \%$ of the world's goat and sheep population. The Indian leather industry locates in northern, central, and southern parts of India, as shown in Fig. 10. India has terrible water pollution caused by leather tanneries, which permanently deteriorate the soil.

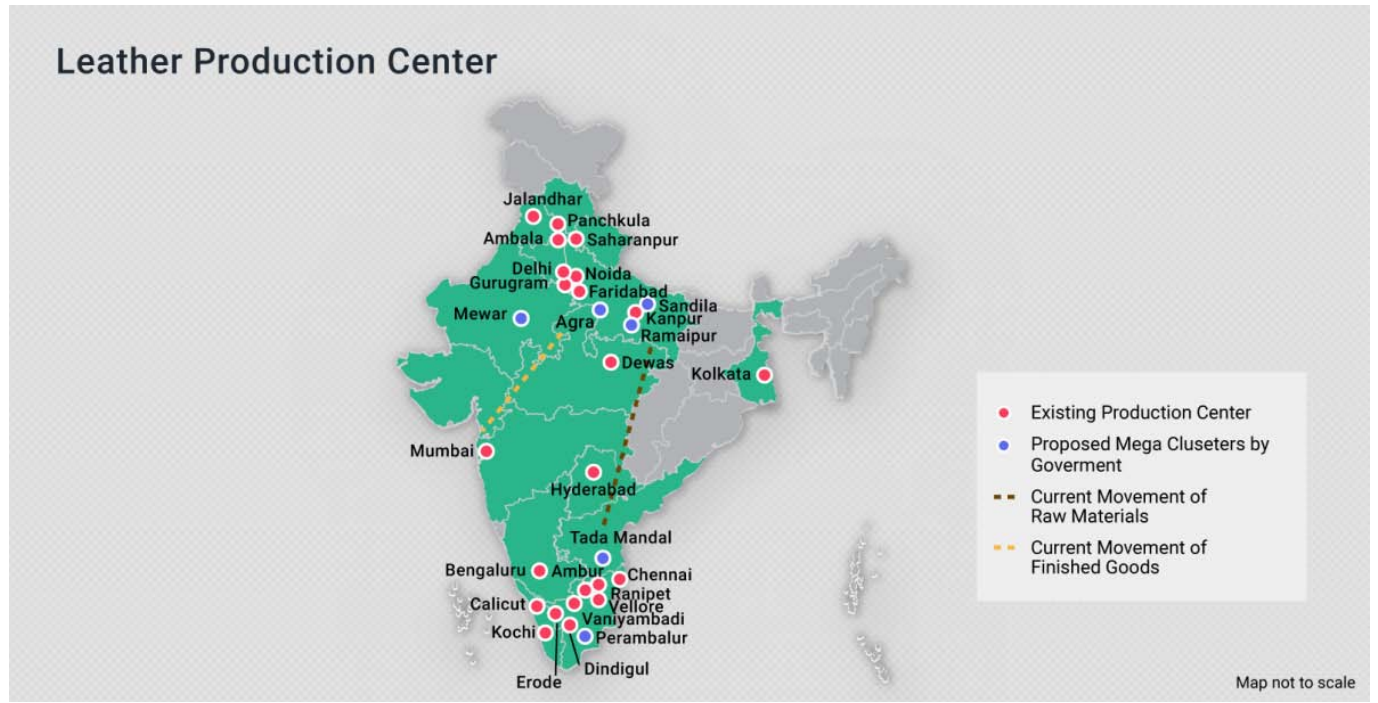

Figure 10: India-leather production center (INSTA REVISION PLAN 2.0, 2020).

India ranks 3rd internationally for $\mathrm{CO}_{2}$ emissions after China and the USA. The main reason for India being ranked 3rd for coronavirus (COVID-19) cases as of July 10,2020 , is the negative parameters of the leather industry and $\mathrm{CO}_{2}$ emissions from oil refineries, power stations, vehicles, and densely populated areas. Positive factors against the coronavirus are curcumin food, volcanoes, and partial safe latitude range near $20^{\circ} \mathrm{N}\left(8-37^{\circ} \mathrm{N}\right)$. Curcuminis a natural anti-inflammatory compound (HE et al.,2015). The COVID-19 induces pneumonia, inflaming the alveoli in the lungs which fill with pus affecting the exchange of oxygen and carbon dioxide molecules to and from the bloodstream, resulting in a shortage of oxygen in the blood culminating in a heart attack (KIM, 2019). Curcumin should eat to prevent the inflammation caused by the COVID-19 that results in lung disorder. The distribution of coronavirus cases in India is very close to those of the leather industries in India (Fig.10). The COVID-19 in India caused by the leather industry using toxic chemicals and carcinogens, which polluted the biosystem in the river and contaminated the water for drinking water. India ranked 3rd globally for deaths $(21,604)$ as of July $10,2020$.

\section{d) Russian Federation}

The Russian Federation ranked 4th globally for $\mathrm{CO}_{2}$ emissions $\left(1,692.8 \mathrm{Mt} \quad \mathrm{CO}_{2}\right) \cdot \mathrm{CO}_{2}$ emissions produced by 25 coal-and gas-powered plants, oil refineries,51,355,000 registered vehicles' exhaust gases, metropolitan food waste gas, human exhalation with population of 144.5 million, leather-tannery industry, and the organic dye industry. Russian electricity bases on gas (46\%), coal (18\%), hydro (18\%), and nuclear (17\%) power. There are twelve volcanoes in Russian Federation. The global Russian rank of the leather production is the fourth (BUFFALO JACKSON, 2020). 
The Russian Federation has the longest coastline measuring $37,653 \mathrm{~km}$ to induce the COVID-19through dolphins and humpback whales (Site \# 1 West Indies, \# 2 Cape Verde, \# 4 Hawaii, \#5 Mexico, \# 6 Southeastern Pacific) (KIM, 2020), migrating to the Arctic Ocean. Since most of the Russian coastline is above the Arctic Circle $\left(66^{\circ} \mathrm{N}\right)$, the impact of the COVID19 reduces by the potent UV-B radiation due to the Arctic ozone depletion (OZONE HOLE, 2019). Even though the Russian Federation has a leather tanning industry and its $\mathrm{CO}_{2}$ emissions ranked 4th in the world, it had relatively few COVID-19 deaths due to the high latitude $\left(60^{\circ} \mathrm{N}\right)$, ranking 4 th with 11,000 deaths as of July 10, 2020.

\section{e) Peru}

$\mathrm{CO}_{2}$ emissions were 57.7 million metric tons from one coal-and sevengas-powered plants, 36 oil refineries, 2,444,000 registered vehicles' exhaust gases, metropolitan food waste gas, human exhalation from a population of 32 million, leather-tannery industry, and the organic dye industry. Peru produced hides to export leather to the USA, Europe, and China, leading to excessive outbreaks of the coronavirus. There are twenty-one active volcanoes. The volcanic gas $\left(\mathrm{H}_{2} \mathrm{O}\right.$, $\mathrm{CO}_{2}, \mathrm{SO}_{2}, \mathrm{CO}, \mathrm{H}_{2} \mathrm{~S}, \mathrm{HCl}, \mathrm{HF}$ ) inhibits the activity of the COVID-19. Thelatitude is $10^{\circ} \mathrm{S}$ and thus within the safe zone from the COVID-19. The coastline is $2,414 \mathrm{~km}$, which induces the COVID-19 through dolphins and humpback whales (Site \# 13 in the Southeastern Pacific) (KIM, 2020), as shown in Fig. 5.Peru ranked 5th globally for deaths $(11,314)$ as of July 10, 2020.

\section{f) Chile}

Chile had a population of 18 million and the coastline extending $6,435 \mathrm{~km}$. $\mathrm{CO}_{2}$ emissions were 90.326 million metric tons, produced by coal-and gaspowered plants, oil refineries,4,445,000 registered vehicles' exhaust gas, metropolitan food waste gas, human exhalation, leather-tannery industry, and organic dye industry. There are 3 active volcanoes. Chile produced hides to export leather to the USA, Europe, and China, leading to excessive outbreaks of the coronavirus. The latitude is $30^{\circ} \mathrm{S}$ and thus not safe from the COVID-19. Chile ranked6thglobally for deaths $(6,682)$ as of July $10,2020$.

\section{g) The United Kingdom}

The United Kingdom ranked 17th globally for $\mathrm{CO}_{2}$ emissions. There is no active volcano. The United Kingdom produces $1,472,000 \mathrm{bbl} / \mathrm{d}$ oil in its refineries and has $\mathrm{CO}_{2}$ emissions of 364.1 million tons. There are 42 natural gas-fired power stations in England along with five coal-powered stations. There were 38.2 million licensed vehicles. Demand for quality leathers increases across the garment, footwear, and leather goods industries. The Stahl Neo company only produces 1,100 leather tanning chemicals. Most tanning does within a few months. In contrast, the traditional tanning process takes 12 months to make expensive, but better leather using the oak bark method. The last oak 13 tanneries in the UK buy top quality hides, using a traditional tanning process, and producing the leather for shoe, saddle and harness makers, which export to China, Turkey, and Italy. Chrome tanning, adding chrome salt to the animal skin, is still the principal method used by $85 \%$ of tanneries because it is fast. Alternatives are the synthetic tanning with glutaraldehyde and vegetable tanning with the tannic acids. There are 12 leather federation associates and 15 UK leather federation members. Effluents from the unhairing and liming processes contain high concentrations of sulfur compounds from the sodium sulfide if the $\mathrm{pH}$ is below 9.5, toxic hydrogen sulfide $\left(\mathrm{H}_{2} \mathrm{~S}\right)$ gas evolves. The latitude is $51.5^{\circ} \mathrm{N}$ and thus not safe from the COVID-19. Since the United Kingdom produces less $\mathrm{CO}_{2}$ emissions than the top 15 countries, it should expect to have less COVID-19 cases. This discrepancy could cause by the active leather tanning industry and toxic chemical manufacturing along with the long coastline of the United Kingdom (4,964 km) where dolphins can swim, as shown in Fig. 5. These combined factors could be responsible for the UK ranked 7 th globally for COVID-19 deaths $(44,687)$ as of July 10, 2020.

\section{h) Mexico}

Mexico ranked $11 \mathrm{~h}$ for $\mathrm{CO}_{2}$ emissions (490.3 Mt $\mathrm{CO}_{2}$ ). The Mexican coastline of $9,330 \mathrm{~km}$ is long enough to induce the COVID-19,through dolphins and whales (Site \#5 Mexico, \# 6 Southeastern Pacific) (KIM, 2020), migrating to the Arctic Ocean. There are 48 volcanoes. Mexico produced hides to export leather to the USA, Europe, and China, leading to excessive outbreaks of the coronavirus (COVID-19). Mexico ranked 8th globally for COVID-19 deaths $(33,526)$ as of July 10,2020 , even though it locates at a safe latitude $\left(19^{\circ} \mathrm{N}\right)$.

\section{i) Spain}

Spain ranked 23rd globally for $\mathrm{CO}_{2}$ emissions (281.4 $\mathrm{Mt} \mathrm{CO}_{2}$ ) and has a population of 46.6 million. There are 11 volcanoes. The latitude is $40^{\circ} \mathrm{N}$ and thus unsafe from the COVID-19. There are seven volcanoes, 2,436 coronavirus cases and 162 deaths (as of July 10, 2020) on the Canary Islands of Spain. Even though there are many volcanoes, not enough fumes are present to prevent the propagation of the coronavirus outbreak. It is, therefore, important to have an active volcano with volcanic gas fumes to inhibit the activity of the coronavirus, as in Japan. Spain has a long coastline of $2,300 \mathrm{~km}$. The relatively high number of deaths could partly cause by its close proximity $(1,595 \mathrm{~km}$ from the Canary Islands) to Cape Verde, which is the humpback whale breeding region in Northwest Africa (Site \# 2)(KIM, 2020). Humpback whale feces can infect the dolphins, which happened in Wuhan in China (KIM, 2019).Spain has $27,463,000$ registered vehicles and a 
population of 46.94 million, producing $\mathrm{CO}_{2}$ emissions. The refinery water consumption estimated (SUN et al.,2018). Spain has an oil refinery capacity of 15 , $515,000 \mathrm{bbl} / \mathrm{d}$ with ten refineries, which produce toxic gases $\left(\mathrm{H}_{2} \mathrm{~S}, \mathrm{SO}_{2}\right)$ as stack gas and polluted water during the process of crude oil, leading to the coronavirus (COVID-19). There are six coal-powered plants and three natural gas-powered plants in Spain to release harmful flue gases $\left(\mathrm{H}_{2} \mathrm{~S}, \mathrm{SO}_{2}\right)$ as a by-product, contributing to the COVID-19. One hundred eighteen companies operated the tanning industry, employing 2,689 workers (SPANISH TANNERS CONFEDERATION, 2008). Tanned Spanish leather intends for footwear followed by leather garments, leather goods, and upholstery, which export to Hong Kong, Italy, France, and Morocco. Leather tanning with chromium salts yields a soft, supple leather that can dye in multiple colors. The key parameter causing the COVID-19 in Spain may be the leather industry and the organic dye industry. The Marshallian Industrial Districts (MID) in Spain produces textile products (46 MID and 85,000 employees) and leather and footwear (23 MID and 73,000 employees). Its main axis extends from the north of Catalonia to Valencia and Murcia. Catalonia, Valencia,

Number of alveoli in lung

$$
\begin{aligned}
& =300 \times 10^{6} \\
& =8 \mathrm{~L} / \mathrm{min} \\
& =\frac{4}{3} \pi \mathrm{R}^{3}
\end{aligned}
$$

Calculation;

Radius of alveolus (R), $R=100 \times 10^{-4} \mathrm{~cm}$

Total Volume

$$
\begin{aligned}
& V=\left(3 \times 10^{8}\right)\left(\frac{4}{3} \pi\right)\left(10^{-6} \mathrm{~cm}^{3}\right) \\
& =4 \pi \times 10^{2} \mathrm{~cm}^{3}
\end{aligned}
$$

Residence Time, $\tau=(\mathrm{V}) /(\mathrm{Q})$

$$
\begin{aligned}
& =\frac{4 \pi \times 10^{2} \mathrm{~cm}^{2}}{8000 \mathrm{~cm}^{3} / \mathrm{min}} \\
& =0.157 \mathrm{~min} \\
& \tau=10 \text { seconds }
\end{aligned}
$$

Therefore, the effect of the COVID-19 is equivalent to giving a straight jab in boxing to an older adult every 10 seconds of residence time (one cycle of air inhalation and air exhalation in the lung), which is very difficult to endure for older adults with high death rate in Europe, China, and the USA. Spain has 282 Metric tons $\mathrm{CO}_{2}$. On the other hand, Spain is the 9th worst-hit country by the COVID-19 with deaths of 28,401 , as of July 10,2020 . It thus suggests that the parameters causing the COVID-19 in Spain are in the significant order of leather-tannery-textile industry, dolphins, oil refineries, power plants, and $\mathrm{CO}_{2}$ emissions.

\section{j) Iran}

Iran ranked 7th globally for $\mathrm{CO}_{2}$ emissions $\left(672.3 \mathrm{Mt} \mathrm{CO}_{2}\right.$ ). The coastline of Iran is $2,440 \mathrm{~km}$. There and Murcia control by a MID basis for better wastewater treatment of polluted effluents from tanned Spanish leather, which could be why such areas showed lower coronavirus cases. High numbers of confirmed cases in other areas could cause by running small factories in residential locations which infect more people due to water pollution as well as air pollution. Such a regional distribution could have caused the high number of deaths in a similar way to Lombardy in Italy, Wuhan in China, and New York City in the USA. Those that have died in Spain could be older than 70 as in other countries. Their respiratory systems had deteriorated for 10-20 years due to air and water pollution in Spain. Their alveoli could no longer exhale $\mathrm{CO}_{2}$ from their bodies, and $\mathrm{O}_{2}$ could not inhale because of chronic calcification by toxic gas pollution $\left(\mathrm{H}_{2} \mathrm{~S}\right)$ from refineries, power plants, vehicles, food waste, and tanneries. However, when affected by the COVID-19, the lung is very weak since the coronavirus calcifies the alveoli of the lung very quickly. Therefore, older adults can die easily unless the oxygen generator supplies in time. The residence time of the COVID-19 can determine with data (KIM, 2020)as follows;

are 14 volcanoes in Iran. The positive parameter against the COVID-19is 14 volcanoes producing volcanic gases $\left(\mathrm{SO}_{2}, \mathrm{H}_{2} \mathrm{~S}, \mathrm{HCl}, \mathrm{HF}, \mathrm{CO}_{2}, \mathrm{CO}, \mathrm{H}_{2} \mathrm{O}\right)$ with two very active sulfur fumaroles in SE Iran, which inhibit the coronavirus activity with weak COVID-19 observed in such regions. The negative parameters are the whale habitat and leather industry. MERS-CoV caused by stranded humpback whales in the Persian Gulf, Gulf of Oman, and Arabian Sea(Kim, 2019). Tabriz with Lake Urmia has the problem of air pollution due to power plants and oil refineries. There are ten oil refineries and 400 power plant units in Iran. The leather industry began with 170 leather companies trading raw hides and skins. The most important parameter is the leather industry (SHAFAEl et al., 2019). Therefore, Iran has high coronavirus casualties due to negative parameters such as the leather industry, oil refineries, power plants, 
vehicles, population density in metropolitan areas of Tehran, water and air pollution, and humpback whales/ dolphins. The latitude of Iran is $32^{\circ} \mathrm{N}$ and thus an unsafe zone from the COVID-19. Iran ranked 10th in the world for deaths $(12,447)$ as of July 10, 2020.

k) Italy

Italy ranked 19th globally for $\mathrm{CO}_{2}$ emissions (60.5 $\mathrm{Mt} \mathrm{CO}_{2}$ ) and had a population of 60.5 million. The coastline of Italy is $7,600 \mathrm{~km}$. There are 48 volcanoes. The latitude is $43^{\circ} \mathrm{N}$ and thus not safe from the COVID19. Italy has $42,242,000$ registered vehicles. There are three major parameters (leather-tannery, dolphins, volcanoes) governing the COVID-19 in Italy. Firstly, leather and textile industries have polluted the PO River (Fig. 11) ever since the Chinese immigrants emigrated Tuscany in Prato (MAX, 2019). Veneto has a total of 1,751 Chinese owned factories. The owner's places of origin are Wenzhou (67.9\%) in China with cloth products. Chinese working conditions were residential areas causing pollution (WUet al., 2011). Since toxic chemicals use for tanning in the leather industry as organic dyes in the textile industry, cities that the PO River passing through (Fig.11), are polluted.

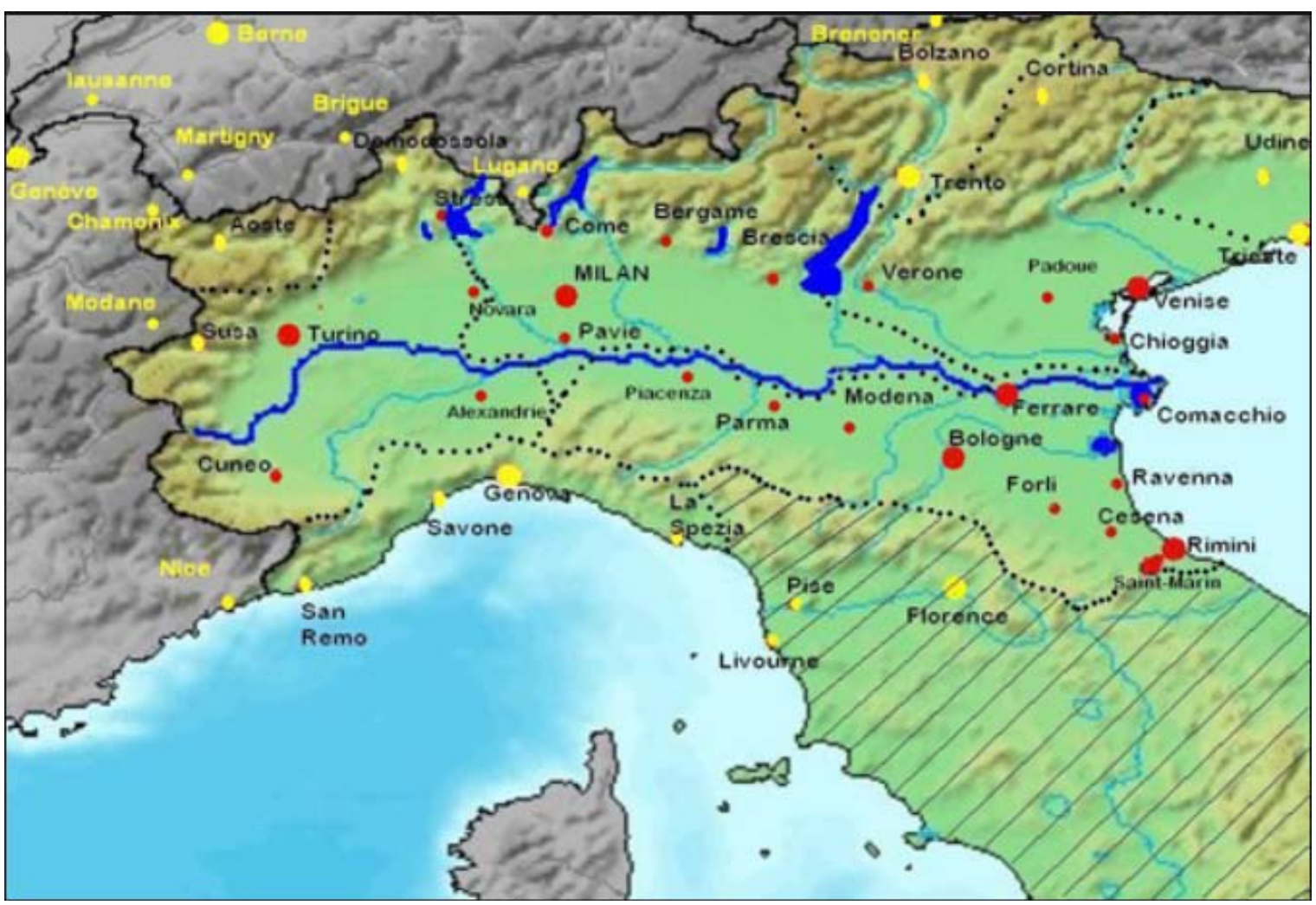

Figure 11: A map of the PO River(from Premier River Cruises by a Travel of America Company), highlighting major Provinces in Italy with confirmed coronavirus cases (deaths); Lombardy 85,775 (15,662), Emilia-Romagna 27,364 (4,008), Piedmont 29,885 (3,718), Veneto 19,030 (1,832), Tuscany 9,982 (998), Marche 6,677 (987), Liguria 9,289 (1,386), Lazio 7,533 (647), Trentino-Alto Adige 4,368 (455), Campania 4,714 (401), and Apulia 4,407 (478) with more than $10 \%$ of deaths. These Provinces have $82 \%$ of Italy's total coronavirus outbreak of 222,364 cases and 32,330 deaths as of May 7, 2020.

The distribution of dolphins in Italy can cause the propagation of theCOVID-19, as shown in Fig. 5. Bottlenose dolphins carried the coronavirus (LEGER et al. 2018). Dolphins, with a worldwide population of about 600,000, swim in shallow areas (25 feet) and are well-distributed in Italy (BAS et al., 2018). Countries that border the Adriatic Sea are as follows with the coronavirus deaths in parenthesis as of June 18, 2020. Italy $(34,448)$, Croatia (107), Slovenia (109), Bosnia and Herzegovina (168), Montenegro (9), and Albania (38). The contribution of the dolphins to the COVID-19 in Italy was moderate while major portions of the Italian coronavirus cases caused by the leather tanneries along

the PO River (Fig. 11) in Northern Italy. The impact of the COVID-19to people is very critical, as shown in Fig. 1, especially the case with older adults who have exposed to air pollution for 20 years by Wenzhou immigrants from China with skills in leather and textile coloring. There are seven active volcanoes (CampiFlegrei, Vesuvius, Stromboli, Panarea, Vulcano, Etna, CampiFlegrei del Mar di Sicilia). Although there were no recent volcanic eruptions, the volcanic activity produced the toxic volcanic chemicals $\left(\mathrm{SO}_{2}, \mathrm{H}_{2} \mathrm{~S}, \mathrm{HCl}, \mathrm{HF}, \mathrm{H}_{2} \mathrm{SO}_{4}\right.$ ) (USGS, 2011). Provinces near volcanoes showed low confirmed coronavirus cases and (deaths): Sicily 3,411 (268), Umbria 1,427 (74), Calabria 1,156 (96), Basilicata 393 
(27), Molise 422 (22) as of May 7, 2020. However, regions of leather and textile industries showed high cases and deaths \%; Lombardy 85,775 (48.4\%), EmiliaRomagna 27,364 (12.4\%), Piedmont 29,885 (11.5\%), Veneto 19,030 (5.7\%), Tuscany 9,982 (3.1\%), Marche 6,677 (3.1\%), Liguria 9,269 (4.3\%), Lazio 7,533 (2.0\%), which are all the regions of the PO River in Fig. 11. Most of the Italian Provinces are in coastal waters where bottlenose dolphins transmit the COVID-19, as proposed by Kim (2020).As for Italy, there are a few features that caused the sudden rise of the coronavirus with high cases and deaths; 1) Italy is famous for its leather and textile industries, which follow the toxic chemical contamination of the PO River, especially by Chinese immigrants in the 1990s in residential areas rather than in industrial complexes. 2) Italy is a Peninsula country having a long coastline of 7,600 km with an average depth of $252.5 \mathrm{~m}$ while the Strait of Sicily is $365 \mathrm{~m}$ deep. Dolphins prefer the shallow coast with a depth of $25 \mathrm{ft}$. It appears that the casualties of the Italian coronavirus (COVID-19) mainly occurred in the region of Lombardy Province with the PO River, polluted by chemicals from leather and textile industries including the regions of Emilia-Romagna, Piedmont, Veneto, Tuscany, and Marche. Dual tracks of the inland leather industry and dolphins off the Italian coasts might have caused the heavy casualties of the coronavirus outbreak in Italy. Furthermore, 100,000 Chinese immigrants from mainly Wenzhou, producing cloth products, polluted residential areas in the region of the PORiver. Besides, Italy has oil refineries with a capacity of $1,898,000 \mathrm{bbl} / \mathrm{d}$. Stack gases such as $\mathrm{SO}_{2}, \mathrm{H}_{2} \mathrm{~S}, \mathrm{CO}, \mathrm{O}_{3}, \mathrm{CO}_{2}$ and hazardous material in oil refineries, induce air pollution with $\mathrm{CO}_{2}$ emissions. Italy ranked 11 th globally for deaths $(34,926)$ as of July $10,2020$.

\section{l) Turkey}

Turkey ranked 15th in the world for $\mathrm{CO}_{2}$ emissions (447.9 $\mathrm{Mt} \mathrm{CO}_{2}$ ). Leather chemicals sell in Turkey (GRAND VIEW RESEARCH, 2019). The leather industry uses very toxic chemicals during leather production, with carcinogenic and derivatives, causing the COVID-19.Turkeyhas 10 volcanoes. The coastline extends for $7,200 \mathrm{~km}$. The latitude is $41^{\circ} \mathrm{N}$ and thus not safe from the COVID-19 resulting in the nation ranked 15th for deaths $(5,300)$ as of July 10, 2020.

\section{m) France}

France ranked 18th globally for $\mathrm{CO}_{2}$ emissions (356.3 $\mathrm{Mt} \mathrm{CO}_{2}$ ). The length of the coastline is $4,853 \mathrm{~km}$. There are 13active volcanoes. The key parameter causing the COVID-19 in France may be the leather industry and the organic dye industry. The latitude is $48.9^{\circ} \mathrm{N}$ and thus out of the safe latitude range. Consequently, France ranked16th globally for deaths $(29,982)$ as of July $10,2020$.

\section{n) Germany}

There are four volcanoes near Frankfurt. Major coal sites are Ruhr, Essen, Saar near Frankfurt with the Rhine River. The central German area where the Elbe River passes through, is near Leipzig, Lusatia, and Helmstedt areas. There are coal-powered plants nearby. There are gas-powered plants all over Germany, and the Inn and Danube Rivers flow through Augsburg and Munich. The latitude of Germany is $51.5^{\circ} \mathrm{N}$ and thus out of the safe latitude range. Germany has the leather textile industry to generate polluted waters, and the oil refineries produce 2,050,000 bbl/d, which in turn to produce toxic stack gases. Dolphins are distributed along the German coastline, which runs for 2,389 km with the North Sea and Baltic Sea spreading the COVID19. The population of Germany was 82.9 million, with 63.7 million registered cars, which produced $\mathrm{CO}_{2}$ emissions of 811 million net tons (meaning a global rank of 6th).There are 1,800 small scale factories and medium-to-large-sized enterprises in the German cloth textile industry with 1,204,500 professional workers (KOPTYUG, 2019).Most German textile companies base in the following regions: North Rhine-Westphalia 202, Baden-Wurttemberg 125, Bavaria 124, Saxony 100, Hessen 43 (https://dw.com/en/love-for-textiles-stillsewn-into-the-fabric-of-saxony-in-eastern_germany).

Major German textile companies correlated with the coronavirus cases distribution along with those of coal- and gas-powered plants. German COVID-19 casualties were mainly caused by the leather textile industry, oil refineries, power stations, vehicle exhaust, and metropolitan food waste biogas. Germany ranked 17th globally for deaths $(9,062)$ from the COVID-19 as of July 10, 2020.

\section{o) Canada}

Canada places 10th in the world for $\mathrm{CO}_{2}$ emissions (572.8 $\mathrm{Mt} \mathrm{CO}_{2}$ ). Canada is one of the major market players of global organic pigments. The coastline extends for $4,964 \mathrm{~km}$. There are five active volcanoes. The latitude of Canada is $53.8^{\circ} \mathrm{N}$ and thus out of the safe latitude range. Since a major part of the Canadian coastline is above the Arctic Circle $\left(66^{\circ} \mathrm{N}\right)$, the impact of the COVID-19reduces by the potent UV-B radiation due to the Arctic ozone depletion (OZONE HOLE, 2019). Canada involves in the leather tanning industry. However, with a high latitude $\left(53.8^{\circ} \mathrm{N}\right)$, it had relatively few COVID-19 deaths $(8,797)$ as of July 10 , 2020 , ranking 20th in the world. The coastline is on the routes of whale migrations to the feeding grounds of the Arctic Ocean in Canada (Humpback whale breeding grounds of Site \# 1 West Indies, \# 4 Hawaii; Gray whale breeding grounds of \#5 Mexico, \# 6 Southeastern Pacific) (KIM, 2020). The major parameters causing the COVID-19 in Canada may be the leather production with toxic chemicals as well as the long coastline for cetacean transmission. 
p) China

China produces the highest amount of $\mathrm{CO}_{2}$ emissions in the world $\left(9,838.8 \mathrm{Mt} \mathrm{CO}_{2}\right)$ and has $162,845,000$ registered vehicles. As of 2019, China had the highest number of installed coal-powered plants, amounting to about 1,005 gigawatts. There are 210 oil refineries. China has 39 volcanoes. But no active volcanoes are present. The population was1.39 billion in 2017. The coastline is $14,500 \mathrm{~km}$. Cetaceans, including whales, dolphins and porpoises, transmitted the COVID19 pandemic $(\mathrm{KIM}, 2020)$. The latitude is $35^{\circ} \mathrm{N}$, and thus, out of the safe latitude range from the COVID-19. China ranked 23th globally for deaths $(4,641)$ as of July 10 , 2020.China released news of 82,929 coronavirus cases with, 6,633 deaths as of May 14, 2020. On the other

$$
\mathrm{CO}_{2} \text { Ratio }=\frac{9.8 \text { (China) }}{5.3 \text { (USA) }}
$$$$
=1.85
$$

China's total cases approximate as,

$(\mathrm{USA} 3,118,168) \times\left(\mathrm{CO}_{2}\right.$ Ratio $\left.=1.85\right)$

$=5,768,610$ (while China official announcement; 84,992 as of July 10, 2020)

$=68$-fold, fewer total cases, announced than those supposed to be in China.

China's deaths cases approximate as,

(USA132,291) X (1.85)

$=244,738$ (while China official announcement;4,641as of July 10,2020 )

$=53$-fold, fewer deaths cases, announced than those supposed to be in China.

It appears that China may have announced68fold fewer casualties, for total cases, and 53-fold fewer ones for deaths cases, of the COVID-19 pandemic than those of actual cases in China.

\section{q) Sweden}

$\mathrm{CO}_{2}$ emissions in Sweden were 63.8 million metric tons in 2018. $\mathrm{CO}_{2}$ emissions produced by 46 coal-, two fuel oil-, and1 gas-powered plant, four oil refineries, 4.8 million vehicles' exhaust gases, metropolitan food waste gas, human exhalation from a population of 10.23 million, four leather-tannery factories, and the organic dye industry. There are no active volcanoes. The latitude is $62^{\circ} \mathrm{N}$ and thus out of the safe latitude range. Since a major part of the Swedish coastline is near the Arctic Circle $\left(66^{\circ} \mathrm{N}\right)$, the impact of the COVID-19 pandemic reduces by the potent UV-B radiation due to the Arctic ozone depletion. Even though Sweden involves in the leather tanning industry and its $\mathrm{CO}_{2}$ emissions were 63.8 million metric tons, the country showed a relatively high level of COVID-19 cases, ranking25th globally for deaths $(5,500)$ as of July 10 , 2020. Good parameters against theCOVID-19 are as follows: Arctic Circle of Norrbotten county has rich forest hand, China announced 84,992 total cases with 4,641 deaths as of July 10, 2020. The number of deaths has significantly reduced since the earlier data of 6,633 on May 14, 2020. Since China produces the highest $\mathrm{CO}_{2}$ emissions, such data is not in agreement with other countries. $\mathrm{CO}_{2}$ emissions in China amount to 9.8 billion metric tons. The USA (5.3 billion metric tons) was the worst-hit by the coronavirus (COVID-19) pandemic with $3,118,168$ total cases and 132,291 deaths as of July 10 , 2020. Since there was a linear relationship between the $\mathrm{CO}_{2}$ emissions and the coronavirus casualties with correlation coefficients of total cases $\left(R^{2}=0.8064\right)$ and deaths $\left(R^{2}=0.7627\right)(K I M, 2020)$, the actual China cases can estimate approximately as follows: area covering $68.92 \%$ of land area and agricultural land covering $7.44 \%$ of land area. The key parameters causing the COVID-19 in Sweden may be the leather production with toxic chemicals as well as the long coastline stretching 3,218 km for cetacean transmission. Residual hazardous chemicals from 20 manufacturers of leather and related products were released into the 12 rivers in Stockholm county, which polluted the water quality and emitted $\mathrm{CO}_{2}$, originated from the flue gas of refineries $(454,000 \mathrm{bbl} / \mathrm{d}, 2018)$ but also from the deteriorated water, similar to the case in Wuhan in China. Organic dyes altering the color of textiles and leather, are the most critical parameters causing the COVID-19 pandemic. There are bottlenose dolphins around in the Baltic Sea. A significant feature of the top 10 counties with coronavirus COVID-19 deaths was a long coastline, which applies to Sweden, as shown in Fig. 5. Coronavirus deaths in Sweden, as of June 04, 2020, indicate per region in parenthesis as follows: Stockholm (12,060), Vastra Gotaland $(5,773)$, Ostergotland $(1,975)$, Uppsala $(1,883)$, Orebro $(1,795)$, Skane $(1,704)$, Sodermanland $(1,623)$, Jonkoping $(1,508)$, Vastmanland $(1,264)$, Gavleborg $(1,258)$, while 
Orebro, Jonkoping, and Vastmanland counties are not in contact with the coastline. It can conclude that the COVID-19 in those three counties are caused purely by the tannery leather and textile industries while the spread of the COVID-19 in the other seven ones caused by mixed types of the leather industry and cetacean transmission. There are 4.8 million vehicles, as well as a total population of 10 million in Sweden. Vehicle exhaust gases and personal exhalation produce $\mathrm{CO}_{2}$ emissions, which increase the COVID-19 cases. The automobile industry is of major importance for Sweden. The map ofCOVID-19 confirmed cases in Sweden completely matched with the figures of the automotive industry in Sweden 2015 (POHL, 2017). It can conclude that the COVID-19 in Sweden caused by the automobile industry using leather goods as interior seats of automobiles, including tannery goods. At the same time, dolphins transmitted the COVID-19 to the counties on the coast of the Baltic Sea. These dual tracks from the land of the automobile industry with leather tanning and from the sea by dolphins, for the coronavirus (COVID19)transmission, might be why Sweden ranked 25th for COVID-19 cases, as of July 10, 2020, which is despite Sweden being ranked far down the international list in 70th for $\mathrm{CO}_{2}$ emissions (44.8 $\mathrm{Mt} \mathrm{CO}_{2}$ / year).

\section{r) Indonesia}

Indonesia ranked 10th globally for $\mathrm{CO}_{2}$ emissions (486.8 $\mathrm{Mt} \quad \mathrm{CO}_{2}$ ). There are 76 active volcanoes. Indonesia has 1,057,000 bbl/d of oil refinery capacity, which produces toxic stack gases, inhibiting the activity of the coronavirus. Other negative parameters inducing the COVID-19 are dolphin residency, and Chinese people arriving on business from Wuhan in China. There is a high population of Chinese Indonesians (nearly 3 million), 38 coal-, 15 oil-, and natural gas-powered plants, nine oil refineries, $22,513,000$ registered vehicles, a high population of 264 million. Indonesia has dolphins along the $54,716 \mathrm{~km}$ coastline. Indonesia is an exporter of raw leather material to the world, which causes pollution in the water as well as in the air, leading to its global rank of 26th for deaths $(3,469)$ as of July 10,2020 . Its rank reduced by the safe latitude $\left(6^{\circ} \mathrm{N}\right)$, active volcanoes (76 actives), and enough forest (52.1\%) and agricultural land (31.46\%) to convert harmfulCO $\mathrm{C}_{2}$ to good $\mathrm{O}_{2}$ against the COVID-19 pandemic.

\section{s) Ecuador}

$\mathrm{CO}_{2}$ emissions were 40.0 million metric tons. The coastline is $2,237 \mathrm{~km}$. There are 27 volcanoes. The latitude is $2^{\circ} \mathrm{S}$ and thus within the safe latitude range from the COVID-19. There are three oil refineries with a net capacity of $175,000 \mathrm{bbl} / \mathrm{d}$. Volcanic gases and stack gases from oil refineries such as $\mathrm{H}_{2} \mathrm{~S}$ and $\mathrm{SO}_{2}$ help reduce the coronavirus cases, as explained in Equation (2) for New Zealand (22) and Iceland (10) with deaths in parenthesis. One out of 50 firms used the traditional vegetable tanning without chemicals (GERULAITYTE, 2018). Provinces near Cotacachi, such as Esmeraldas (43) and Imbabura (11), had a relatively low number of deaths. There were many deaths in the provinces of Guayas (1,059), Manabi (252), Pichincha (105) via Los Rio (76), and El Oro (114), as of May 14, 2020. Those provinces are all in contact with either the Pacific Coast, estuaries or rivers. Dolphins live off the Ecuadorian Coasts and in the Rivers. The high casualties in Ecuador were all shown in the areas of the coast, the estuarine, or where dolphins can approach. Ecuador ranked 29th globally with 64,221 total cases and4,900 total deaths as of July 10, 2020.

\section{t) Belgium}

$\mathrm{CO}_{2}$ emissions in Belgium were 94.7 million metric tons, produced by three coal-poweredand18 gas-powered plants, four oil refineries, $6,426,000$ registered vehicles producing exhaust gases, metropolitan food waste gas, human exhalation gas from a population of 11.5 million, seven leather-tannery factories, and the organic dye industry. Belgium is one of the leading exporters of leather footwear. The key parameters causing the COVID-19 in Belgium may be the leather industry and the dye industry. Belgium ranked 30th globally with 62,357 total cases and9,781 deaths as of July 10, 2020.

\section{u) The Philippines}

The Philippines had a population of 106.7 million and produced 157.6 million metric tons of $\mathrm{CO}_{2}$ emissions. The Philippines have 23 active volcanoes, the volcanic fumes of which might reduce further casualties in the Philippines. Good parameters for the Philippines against the COVID-19 are volcanoes and a safe latitude location. Negative ones in favor of the COVID-19are $\mathrm{CO}_{2}$ emissions, dolphins along the 36,289 $\mathrm{km}$ coastline, the population of 105 million, 19 coalpowered plants, ten diesel-powered plants, five gaspowered plants, three oil refineries, and the leather industry. There are many Chinese people from Wuhan of China working in the leather industry, which causes water pollution by toxic chemicals in the leather tanning process. The latitude of the Philippines is $14^{\circ} \mathrm{N}$ and thus within the safe latitude range of the COVID-19, ranked 35th globally for deaths 1,360 as of July 10, 2020.

\section{v) The Netherlands}

$\mathrm{CO}_{2}$ emissions were 163.4 million metric tons and has a population of 17.3 million. There are two active volcanoes, nine oil refineries, 12 coal- and 12 gas-powered power plants, and dolphins causing the coronavirus outbreak. The coastline is $451 \mathrm{~km}$. The latitude is $52^{\circ} \mathrm{N}$ and thus not safe from the COVID-19. Netherlands ranked 37th globally with6,156 deaths as of July 10, 2020. 


\section{W) Israel}

$\mathrm{CO}_{2}$ emissions in Israel were 64.6 million metric tons, produced by coal-and gas-powered plants, oil refineries,2,959,000 registered vehicles' exhaust gases, metropolitan food waste gas, human exhalation from a population of 8.88 million, and leather-tannery industry. The coastline is $273 \mathrm{~km}$. There are no volcanoes. The latitude is $31^{\circ} \mathrm{N}$ and thus out of a safe zone from the COVID-19. In Israel, there were 7,440 workers in 2,580 firms in the leather industry in 1965. Most work was done in140 family-style workshops by 1,500 persons (ENCYCLOPEDIA JUDAICA, 2008) (https://www. jewishvirtuallibrary.org/leather-industry-trade). Principal casualties occurred in Tel Aviv, Jerusalem, and Hebron. Harmful causes stimulating the coronavirus outbreak are as follows; the leather and apparel industry, textile industry, dolphins off the Mediterranean coast, two oil refineries $(305,000 \mathrm{bbl} / \mathrm{d}), 25$ natural gas-powered plants with significant gas discoveries in Israel. It is likely that the pollution caused by tanneries and shoemaking induced COVID-19 cases. The Yarkon River flows west through Tel Aviv as the largest coastal river in Israel with principal rivers of the Jordan, Qishon, and Yarkon, polluted by the tannery-leather-footwear-apparel industry to induce a significant number of COVID-19 pandemic. Israel ranked 44th globally for deaths 350 as of July 10, 2020.

\section{x) Japan}

Japan ranked 5th globally for $\mathrm{CO}_{2}$ emissions $\left(1,205.1 \mathrm{Mt} \mathrm{CO}_{2}\right)$ with a population of 126.8 million. The coastline of Japan is $29,751 \mathrm{~km}$. There are 110 volcanoes. The latitude is $35^{\circ} \mathrm{N}$ and thus not safe from COVID-19 pandemic. Favorable parameters against the coronavirus are 110 active volcanoes, rich forests and mountains (67\%), and agricultural land (12.26\%). Negative parameters are as follows:

Leather. Hyogo leather's white color naturally creates by the tanning process. Japan produces textiles to cause the water pollution and worsen the coronavirus outbreak. Dolphins. Approximately 22,000 dolphins killed annually for Japanese meat. Dolphins lead to a high number of coronavirus (COVID-19) cases (KIM, 2020). Oil refineries and power plants. Japan has 23 refineries with a capacity of 3.92 million bbl/d. Japan has built two coal-burning power plants and four natural gas power plants. Stack gas from the refineries and flue gas from the power plants cause air pollution with enhanced $\mathrm{CO}_{2}$ emissions and toxic $\mathrm{H}_{2} \mathrm{~S}$ and $\mathrm{SO}_{2}$, inducing the COVID-19.Vehicles and population. There were 78.3 million vehicles, as well as a total population of 126.5 million. Vehicle exhaust gases and all the people produce $\mathrm{CO}_{2}$ emissions to increase the COVID-19.

Active volcanoes. One hundred ten active volcanoes are now protecting Japan from the coronavirus disaster. Volcanic eruptions produce volcanic gases such as $\mathrm{SO}_{2}$ and $\mathrm{H}_{2} \mathrm{~S}$, which are very acidic, which the coronavirus does not like. When comparing the 47 Japanese Prefectures with the COVID-19 outbreak as of July10, 2020, two characteristic groups observed. The first group is Prefectures far from volcanoes with excessive casualties; Tokyo (confirmed cases 7,515/325 deaths), Osaka (1,967/86), Kanagawa (1,685/97), Chiba $(1,078 / 46)$, Saitama (1,396/67), Hyogo (726/43), Fukuoka (908/33), Hokkaido (1,289/101), Aichi (531/34), Kyoto (430/18), Ishikawa (300/27), Ibaraki (196/10), Gifu (162/7). The second group is Prefectures near the volcanoes with negligible casualties; Northeast Honshu Arc area of Aomori (29/1) (Mt. Iwaki), Iwate (0/0) (Mt. Iwate), Akita (16/0) (Mt. Akita-Yakeyama), Southwest Honshu Arcarea of Tottori (4/0) (Mt. Daisen), Shimane (24/0) (Mt. Sanbe), Okayama (28/0) (Mt. Shintake), Tokushima (10/1) (Mt. Ishizuchi), Ryukyu Arcarea of Saga (47/0) (Mt. Sefuri), Nagasaki (20/1) (Mt. Unzen), Miyagi (100/1) (Mt. Kirishima), Miyazaki (17/0) (Sakurajima Volcano), Kagoshima (132/0)(Mt. Sakurajima). The second group near active volcanoes, which shown in parenthesis, had the least COVID-19 cases and a negligible number of deaths. The comparison indicated that the COVID-19 deaths were reversely proportional to the presence of active volcanoes or volcanic gases from volcanoes, as shown in CASE 1 of Equation (2). Therefore, in non-volcanic countries, people can easily protect themselves from the COVID-19 pandemic by spraying small amounts of artificial volcanic gases such as $\mathrm{SO}_{2}$ and $\mathrm{H}_{2} \mathrm{~S}$, as described in the section of II. e).Japan ranked56th globallyfor deaths 982 as of July 10, 2020.

\section{y) South Korea}

South Korea ranked 9th globallyforCO emissions (616.1 $\mathrm{Mt} \mathrm{CO}_{2}$ ) and has a population of 51.5 million. There are no volcanoes. The latitude is $37.5^{\circ} \mathrm{N}$ and thus not safe from COVID-19. Helpful parameters are such as clean forestry and rivers with even distribution of industrial complexes along the coastline. The textile industry for coloring and dolphins. South Korea had the most casualties in Daegu city, which has 109 dyeing factories (as of 1994). They used toxic chemicals such as Chinese dyes, domestic caustic soda, sulfuric acid, hydrochloric acid, acetic acid, and surfactant, for coloring. Residual harmful chemicals released into the Geumho River in Daegu city, which polluted the water quality and emitted carbon dioxide from the flue gas. Indo-Pacific bottlenose dolphins can be found around Jeju Island in South Korea, and common dolphins can find in the coastal area of Ulsan and Pohang, and in coastal areas in the Yellow Sea between China and South Korea. Since not many dolphins approach the South Korean coast, their effect on the COVID-19 was minor. Oil refineries, natural gasand coal-powered power plants. There are five oil refineries with a refinery capacity of 2,799,000 bbl/d. 
Since they locate on the coastal areas, their stack gases fly over the East Sea or the Yellow Sea, providing toxic stack gas enough to repel the coronavirus activity. Significantly, there are no deaths in the well distributed oil refinery cities of Ulsan (East Sea), Yeosu (South Sea), Daesan (Yellow Sea middle), and Incheon(Yellow Sea top). There are 33 coal-powered plants on the coasts of the Yellow Sea and the East Sea, which emit flue gases that fly over the seas without seriously affecting the COVID-19. No power plants are present in residential areas. Vehicles and population are well-distributed around South Korea. Forest (63.35\%) and agricultural lands $(22 \%)$ of South Korea are covered by green zones with clean air from the conversion of harmful $\mathrm{CO}_{2}$ to good $\mathrm{O}_{2}$ which acts against the COVID-19. South Korea is, however, vulnerable to the COVID-19because of the textile and dye industry in Daegu city, which led to significant (66\%) casualties (189 deaths with 288deaths nationally) from the COVID-19 pandemic as of July 10 , 2020. South Korea ranked 64th globally with deaths 288 as of July 10, 2020.

\section{Conclusion}

The present study proposes vaccine, protection, emergence, propagation, and termination associated with the coronavirus (COVID-19) pandemic. The case studies for 25 worst-hit countries showed major causes such as leather tanning industry $\left(R^{2}=\right.$ $0.8514)$, global coastline $\left(R^{2}=0.7864\right)$, USA coastline $\left(R^{2}\right.$ $=0.3099)$, USA refinery $\left(R^{2}=0.4874\right), C O_{2}$ emissions $\left(R^{2}=0.7627\right)$, population $\left(R^{2}=0.3748\right)$, and minimum sunspot number $\left(\mathrm{R}^{2}=0.8907\right)$ withCOVID-19pandemic. Therefore, COVID-19 can globally decrease by reducing toxic chemicals during leather industry.

The present study proposes that the11-year cyclic sunspot number is analogous to a SWITCH, turning ON and OFF an epidemic, inducing a publichealth crisis. The ON period by the minimum(maximum) sunspot number initiated mutant viruses (AIV, SARS, MERS-CoV, and COVID-19) to transmit from the Poles to Continents by migratory birds and humpback whales. The firstCOVID-19arrival dates in China, USA, Japan, Mexico, and Hawaii, determined by the distance between feeding grounds and breeding areas of humpback whale habitats.

The breeding period of the whales is from December to April, while the feeding period is from May to September (or from June to October). The human incubation period is from 2-14 days to possible outliners 0-27 days. Therefore, the termination of COVID-19 expects in July with an additional one month of human incubation to June. However, it takes another one month for whale migration to be August as the ultimate termination timing of the COVID-19.

There can be a competition of virus survival between the present COVID-19 and the newly arrived virus for a few months. Similarly, a new type one may appear in September of 2020 from the Poles. There can be a competition of virus survival between the COVID-19 and the newly arrived virus at Continents for a few months so that the COVID-19 may competitively inhibit the new virus and fade away, as used to occur in toxic cyanobacteria in the lake. The OFF period occurs during the high sunspot number ( $>$ around 25-50) and may terminate the COVID-19 pandemic in September (optimistic prediction) or in November 2020 (pessimistic one).

The COVID-19 vaccines,1) sample both at the Arctic Ocean and the Antarctic Peninsula for the feeding grounds of humpback whales,2) culturing plasma from people who have recovered from COVID-19 and plasma from CMV infected cetaceans, 3) 4 kinds of plasma preparations depending on the source (humans and cetaceans) and virus diseases (COVID-19 and CMV) as; fresh human plasma, human one confirmed by COVID19, fresh cetacean plasma, and cetacean one infected by $\mathrm{CMV}, 4)$ inoculates and incubates at $37^{\circ} \mathrm{C}$ while the virus inactivates at a high temperature, 5) use as one of 5 types of vaccines among live attenuated, inactivated, toxic, subunit, and conjugate ones,6) application to humans by the stepwise methods in vitro P3 Lab test at petri dish for the initial efficacy of curing the human lung cell infected by the COVID-19. In vivo human tests (confirmed, recovered, and healthy), determine the final efficacy and the stability of the developed COVID-19 vaccines to protect the human body's immune system to reduce the COVID-19 symptoms,7)genetic modification of the present MMR (Measles, Mumps, and Rubella) vaccine with the cetacean host, may allow the low titers of the attenuated COVID-19vaccines to last long and safe.

Screenings by physical (body temperature), chemical $\left(\mathrm{H}_{2} \mathrm{~S}\right.$ detector), biological (blood test), and radiological (computerized tomography) kits may separate the infected patient from the healthy ones for the safe situation from the COVID-19 pandemic.

As for the emergence of COVID-19, the breeding period of humpback whales begins from December to April. Adding one month for the human incubation period of COVID-19 pandemic to December, it expects that the COVID-19 pandemic would emerge in January 2020. On January 19, 2020, a 35-year-old man in Seattle of Washington was the first case of COVID-19 in the USA, while on January 16, 2020 there was the first case of COVID-19 in Japan.

An additional month added to January can be applicable if the route is from Alaska to the breeding grounds of Baja California of Mexico with a distance of 4,374 km. Thus, the first case of COVID-19 in Mexico was February 28, 2020 as arrival date, which was close to one month added to the case of Seattle (January 19, 2020). The distance between Hawaii and the Bering Sea in Alaska is $4,486 \mathrm{~km}$, which is a little farther than Baja 
California of Mexico. If subtracting $4,374 \mathrm{~km}$ of Baja California of Mexico (February 28, 2020) from 4,486 km of Hawaii, the answer is 5 days additional to February 28, 2020, to be the same March 6, 2020,as the first confirmed cases of COVID-19 in Hawaii. It can conclude that the first arrival dates of the COVID-19 in Seattle in the USA, Japan, Mexico, and Hawaii, determined by the swimming distance between the feeding ground and the breeding ones of humpback whale habitats.

As for China, there was the first case of COVID19 in Wuhan on November 17, 2019. Ward observed over 100 dead dolphins found dead on the beach of Cape Verde of West Africa on September 28, 2019. The distance between Cape Verde and Wuhan in China is $20,222 \mathrm{~km}$ to have traveling time of 38.3 days. If adding 38.3 days to the observed date by Ward, September 28, 2019, the resultant day was November 7, 2019. Since the incubation period of the COVID-19 was 2-14 days, the expected day of the COVID-19 emergence in Wuhan in China was between November 9, 2019, and November 21, 2019, while the actual emergence date in China was November 17, 2019. It is certain that the date of the COVID-19 emergence in Wuhan in China initiated by the cetacean swimming distance from Cape Verde to Wuhan in China. The largest $\mathrm{CO}_{2}$ emissions in China might cause the largest ozone hole area and the highest UV-B radiation for the earliest emergence of COVID-19in China during the minimum sunspot number.

There were three typical cases of COVID-19 termination, based on the newly reported case by day in coronavirus map and case count by the New York Times as follows.

Case 1 with bell curve decrease; Tokyo, Germany, U.K., Italy, Spain, France, Canada, USA (NY, $\mathrm{NJ}, \mathrm{RI}, \mathrm{NH}, \mathrm{MD}, \mathrm{MA}, \mathrm{CT}, \mathrm{AZ}, \mathrm{UT}, \mathrm{DC})$, Case 2 with stepwise increase; Brazil, Mexico, India, Russia, Peru, Ecuador, Chile, Belgium, USA (CA, FL, NC, SC, GA, AZ, OR,TX, AL, ID, TN, WI, MI, MO, AR, KY, NV, NE, WY, AK, $P R$ ), Case 3 with see-saw increase; Israel, USA (ME VA, PA, DE, WA, CO, MI, IL, VT, LA, OH, IN, MN, IA, KS, WV, $\mathrm{SD}, \mathrm{ND}, \mathrm{HI})$.

The main parameters caused by the COVID-19 for Case 1 could be the cetaceans, including whales, dolphins, and porpoises. Case 2 could be the leather tannery industry; exporting hides to other countries. Case 3 for the mixed causes. Japan's virus success simply caused by the presence of volcanic gases from volcanoes, whose acidity and toxicity inhibited the coronavirus (COVID-19) pandemic, as in other volcanic countries such as Italy, Indonesia, Philippines, and Ecuador.

\section{ACKNOWLEDGMENT}

The author expresses sincere gratitude to the University of Suwon, WARE VALLEY, and G-LAND of South Korea for their financial supports. Editing and typing works undertaken by Professor Jonathan Wright are also greatly appreciated.

\section{References Références Referencias}

1. Azo Cleantech(2019). What are vehicle exhaust emissions? Clean Tech 101. 19th of August 2019.

2. Bas A A et al. (2015). Selection of critical habitats for bottlenose dolphins (Tursiops truncates) based on behavioral data, in relation to marine traffic in the Istanbul Strait, Turkey. Marine Mammal Science. 31: 979-997.

3. Bluegold Research, Seeking Alpha (2020). Energy information administration, Bluegold Research estimates, and calculations. March.

4. Buffalo Jackson (2020). Which countries produce the most leather 2020? 2020 Buffalo Trading Company.

5. Casola, A (2018). Role of hydrogen sulfide in viral infections. National Institute of Health.

6. Callaway E (2020). Coronavirus vaccine trials have delivered their first results- but their promise is still unclear. NEWS. 19 May 2020.

7. Callaway E, Ledford H, Mallapaty S (2020). Six months of coronavirus: the mysterious scientists are still racing to solve. Nature. 583:178-179. 09 July 2020.

8. Centers for Disease Control and Prevention, CDC (2017). Influenza type A viruses. CDC 24/7. National Center for Immunization and Respiratory Diseases (NCIRD).

9. Centers for Disease Control and Prevention, CDC (2018). Understanding how vaccines work.

10. CGTN America (2020). Who is 'patient zero' of COVID-19 pandemic? Here's what we know. March 30,2020

11. CIA (2020). Field listing: Coastline-The World Factbook.

12. Corman V M et al. (2018). Hosts and sources of endemic human coronavirus. Adv. Virus Res.100: 163-188.

13. Dumont $\mathrm{E}$ (2015). $\mathrm{H}_{2} \mathrm{~S}$ removal from biogas using bioreacrors: a review. International Journal of Energy and Environment. International Energy \& Environment Foundation. 6: 479-498. Hal-01945143.

14. ECOPOL-Home (2020). https://leathersustainability. weebly.com.

15. Encyclopedia Judaica (2008). Leather Industry and Trade- Jewish Virtual Library. The Gale Group..https://www.jewishvirtuallibrary.org/leatherindustry-trade

16. Fleming $S$ (2019). Chart of the day: These countries create most of the world's $\mathrm{CO}_{2}$ emission. World Economic Forum. 07 June 2019.

17. Frohlich T C, Blossom L (2019). China, US: These countries produce the most $\mathrm{CO}_{2}$ emissions. Stylish Stories. Northjersey.com. July 23, 2019. 
18. Fuller et al., (2010). Mapping the risk of avian influenza in wild birds in the US. BMC Infectious Diseases. 10:187.

19. Gallagher T H, Schleyer A M (2020). "We signed up for this!" - Student and trainee responses to the covid-19 pandemic. N. Engl. J. Med. 382: e96. Doi: 10.1056/NEJMp2005234.

20. Giugliano M, Ranzi E (2016). Thermal treatments of waste. waste to energy. Reference Module in Chemistry. Molecular Sciences and Chemical Engineering. Doi: 10.1016/B978-0-12-4095472.11523-9).

21. Grand View Research (2019). Global leather chemicals market size. Industry Report 2019-2025.

22. Hathaway DH (2010). The Solar Cycle. Living Reviews in Solar Physics. 7. 1. https://doi.org/ 10.12942//rsp-2010-1.

23. He, Y, Yue $Y$, Zheng $X$, Zhang $K$, Chen S, Du Z (2015). Curcumin, inflammation, and chronic diseases: How are they linked? Molecules. 20: 9183-9213.

24. Ichikawa S, Takahashi C S, Nagashimal C (1981). Somatic mutation frequency in the stamen hairs of Tradescantia KU 7 and KU 9 clones exposed to lowlevel gamma rays. Jpn.. J. Genet. 56: 409-423.

25. Insta Revision Plan 2.0 Day-18 (2020).

26. Japan Times (2020). Japan confirms first case of coronavirus that has infected dozens in China. Kyodo. January 16, 2020.

27. Jo W K et al. (2018). Evolutionary evidence for multihost transmission of cetacean morbillivirus. Emerg Microbes Infect. 7: 201.

28. Johns Hopkins Coronavirus Resource Center (2020). Johns Hopkins University.

29. Kim T J (2018). Prevention of avian influenza virus by ultraviolet radiation and prediction of outbreak by satellite parameters. Journal of Biomedical Science and Engineering. 11: 182-206.

30. Kim T J (2018). Transmission of avian influenza virus by humpback whale and its stranding along the Atlantic Coast with $\mathrm{CO}_{2}$ emissions. Journal of Biomedical Science and Engineering. 11: 359-381.

31. Kim T J (2019). Predictions of El Niño, La Niña and record low Chicago temperature by sunspot number. Natural Science. 11: 204-220.

32. Kim T J (2019). Transmission and prevention of Wuhan coronavirus disease 2019 (COVID-19) during minimum sunspot number. Global Journal of Medical Research: F Disease. 20 (3): 13-33.

33. Kim $T J$ (2020). Causes and preventions of coronavirus (COVID-19) during minimum sunspot number. Global Journal of Medical Research: KInterdisciplinary. 20 (7):5-28.

34. Koptyug E (2019). Forecasted revenue development in textiles and clothing in Germany 2011-2023 consumer goods \& FMCG. Statista.
35. Leger J S, Raverty S, Mena A (2018).Cetacea, Chapter 22. Pathology of Wildlife and Zoo Animals. 533-564, 564.e1-564.e8, 565-568. Doi: https:// doi.org/10.1016/B978-0-12-805306-5.00022-5

36. Max, D T (2018). The Chinese workers who assemble designer bags in Tuscany. Chinese Heritage Foundation. New Yorker Magazine. April 16, 2018.

37. Memodovic O, Mattile H (2008). The global leather value chain: the industries, the main actors and prospects for upgrading in LDCs. Internal Journal of Technological Learning. Innovation and Development I. 482-519.

38. Modrow S, et al. (2013). Viruses with singlestranded, positive-sense RNA Genomes. In Molecular Virology, 185-349. Springer. Berlin. Heidelberg.

39. National Institutes of Health (1989). Sunlight, UV radiation, and the skin. $\mathrm{NIH}$ Consensus Statement. May 8-2010. 7(8): 1-29.

40. National Oceanic and Atmospheric Administration (NOAA) Fisheries (2015). Humpback whale (Megapteranovaeangliae). April 21, 2015. www.nmfs.noaa.gov/pr.

41. Ozone Hole: The Arctic (2019). Ozone Depletion. https://www. ozone-hole.org.uk/08.php

42. Piechotta $\vee$ et al. (2020). Plasma from people who have recovered from COVID-19 to treat individuals with COVID-19. Cochrane Library. Haematology Group. WHO. 10 July 2020.

43. Pohl H (2017). The automotive industry in Sweden. A cluster study. Vinnova Analysis VA. 2017: 04.

44. Rigby M (2019). Increase in CFC-11 emissions from eastern China based on atmospheric observations. Nature. 569: 546-550.

45. Saxena G, Chandra R, Bharagava R N (2016). Environmental pollution, toxicity profile and treatment approaches for tannery wastewater and its chemical pollutants. Reviews of Environmental Contamination and Toxicology. 240.

46. Shafaei R, Shahriari H, Moradi M (2019). Investigation of leather industry competitiveness in Iran. Journal of Fashion Marketing and Management. 13: 343-357.

47. SinoBiological (2020). Coronavirus vaccine.

48. SKYbrary Flight Safety (2017). Exhaust gas temperature (EGT).

49. Solar Dynamics Observatory (2008). Average sunspot number 1980 - 2008. NASA.

50. Sorace $S$ (2019). More than 130 dolphins dead in mysterious mass stranding. Fox News. New York Post. September 30, 2019.

51. Southern Times (2019). Zim scientists discover 'ozone hole' over South Africa. February 25.

52. Space Weather Prediction Center (2020). Daily sunspot number. NOAA. 
53. Space Weather Services. (2020).Monthly Sunspot Numbers. Bureau of Meteorology. Australian Government.

54. Spanish Tanners Confederation CEC-FECUR (2008). Social report and environmental report 1. of the Spanish leather industry.

55. Sun P, Henderson R J (2018). Estimation of refinery water consumption and allocation to refinery products. Fuel. 221:542-557.

56. United States Geological Survey USGS (2011). Volcano Hazards Program 22.

57. University of Alabama at Birmingham (2007). Garlic boosts hydrogen sulfide to relax arteries. Science Daily. October 17, 2007.

58. Walzer J B (2016). Leather industry, Encyclopedia of Milwaukee. https://emke.uwm.edu/entry/leatherindustry/.

59. Ward A (2019). Over 100 dead dolphins found stranded on beach. World News. Animals. LAD BIBLE.

60. Wolfe D (2019). Scientists are worried that a thousand gray whales have died so far this year. Starved and Stranded. San Francisco. July 20, 2019.

61. World Health Organization (2020). Novel Coronavirus- Japan (ex-China).

62. World Health Organization (2020). Draft landscape of COVID-19 candidate vaccines. April 20.

63. Wu B, Sheehan J (2011). Globalization and vulnerability of Chinese immigrant workers in Italy: empirical evidence of working conditions and their consequences. Journal of Contemporary China. 20: 135-152. 